NBER WORKING PAPER SERIES

\title{
LOSING OUR MARBLES IN THE NEW CENTURY? THE GREAT REBALANCING IN HISTORICAL PERSPECTIVE
}

\author{
Christopher M. Meissner \\ Alan M. Taylor \\ Working Paper 12580 \\ http://www.nber.org/papers/w12580 \\ NATIONAL BUREAU OF ECONOMIC RESEARCH \\ 1050 Massachusetts Avenue \\ Cambridge, MA 02138 \\ October 2006
}

\begin{abstract}
Paper prepared for the session "Global Imbalances: Lessons from History," Federal Reserve Bank of Boston Conference, Chatham, Mass., June 2006. Taylor thanks the John Simon Guggenheim Memorial Foundation for its support. The paper was prepared whilst Taylor was a Visiting Professor at London Business School, and Taylor thanks LBS for its support. Meissner thanks the Bank of England staff for valuable conversations. We also thank Michael Bordo and Maurice Obstfeld for helpful discussions. Michael Edelstein, Niall Ferguson, Philip Lane, Gian Maria Milesi-Ferreti, and Helene Rey generously helped us with data. We have received helpful comments from Luis Catao, Michael Edelstein, Marcus Miller, Federico Sturzenegger, Gian Maria Milesi-Ferreti, seminar participants at the Bank of England, Birkbeck College, and many of the conference participants. In particular, we thank our discussants John Helliwell and Suzanne Berger for their thoughtful responses. The usual disclaimer applies. The views expressed herein are those of the author(s) and do not necessarily reflect the views of the National Bureau of Economic Research.
\end{abstract}

(C) 2006 by Christopher M. Meissner and Alan M. Taylor. All rights reserved. Short sections of text, not to exceed two paragraphs, may be quoted without explicit permission provided that full credit, including () notice, is given to the source. 
Losing our Marbles in the New Century? The Great Rebalancing in Historical Perspective Christopher M. Meissner and Alan M. Taylor

NBER Working Paper No. 12580

October 2006

JEL No. F20,F30,F32,F40,F50,N10,N20

\begin{abstract}
$\underline{\text { ABSTRACT }}$
Great attention is now being paid to global imbalances, the growing U.S. current account deficit financed by growing surpluses in the rest of the world. How can the issue be understood in a more historical perspective? We seek a meaningful comparison between the two eras of globalization: "then" (the period 1870 to 1913) and "now" (the period since the 1970s). We look at the two hegemons in each era: Britain then, and the United States now. And adducing historical data to match what we know from the contemporary record, we proceed in the tradition of New Comparative Economic History to see what lessons the past might have for the present. We consider two of the most controversial and pressing questions in the current debate. First, are current imbalances being sustained, at least in part, by return differentials? And if so, is this reassuring? Second, how will adjustment take place? Will it be a hard or soft landing? Pessimistically, we find no historical evidence that return differentials last forever, even for hegemons. Optimistically, we find that adjustments to imbalances in the past have generally been smooth, even under a regime as hard as the gold standard.
\end{abstract}

Christopher M. Meissner

Faculty of Economics

University of Cambridge

Austin Robinson Building

Sidgwick Avenue

Cambridge CB3 9DD

ENGLAND

and NBER

chris.meissner@econ.cam.ac.uk

Alan M. Taylor

Department of Economics

University of California

One Shields Avenue

Davis, CA 95616

and NBER

amtaylor@ucdavis.edu 
The unending feedback of the dollars and pounds received by the European countries to the overseas countries from which they had come reduced the international monetary system to a mere child's game in which one party had agreed to return the loser's stake after each game of marbles-Jacques Rueff, $1961^{1}$

A remarkable amount of attention is now being paid to global imbalances, the growing U.S. current account deficit financed by growing surpluses in the rest of the world, most notably in the Asian "dollar bloc" and among the oil exporters. The talk is no longer confined to obscure academic and policy debates. With insufficient space in his weekly columns to devote to the issue, the Financial Times' Martin Wolf launched a web site stating that "what is happening is extraordinary"; David Warsh considers the almost obsessive focus on the issue justified, since global imbalances constitute "the most exciting economic story of our times.",2

Exciting and extraordinary it may be, but a relentless focus on trends from the recent past, on the current announcements of each quarter's balance of payments data, or on naive extrapolations into the future has left one important perspective rather neglected: how can the issue of global imbalances be understood in a more historical perspective?

To address this question, we seek a meaningful comparison between past and present experience. We focus on the two eras of globalization: "then" (the period 1870 to 1913) and "now" (the period since the 1970s). We look at the special position in the global macroeconomy of the hegemons in each era: Britain then, and the United States now. And adducing historical data to match what we know from the contemporary record, we proceed in the tradition of New Comparative Economic History to see what lessons the past might have for the present.

Although such an exercise in quantitative economic history could range far and wide, in this paper space limitations permit us only to look at what we consider two of the most controversial and pressing questions in the current debate.

First, are current imbalances being sustained, at least in part, by return differentials? And if so, is this reassuring? If the U.S. can always earn some kind of "privilege" of this sort, then the degree of required adjustment will be reduced. Or, putting it another way, for any given trajectory of trade imbalances, we know that the current account and debt implications will look much more favorable or sustainable if such privileges persist. If not, any difficulties will be that much more pronounced.

Second, how will adjustment take place? Will it be a hard or soft landing? It is possible, again, that adjustments will happen smoothly. Depending on the extent to which expenditure shifts rather than switches, countries might avoid dramatic real exchange rate movement. If up and down shifts are coordinated across countries, or if switching is unhindered by trade policies or other frictions, then global demand might hold up, and recession avoided. The fear is that adjustments might be much more abrupt, demand large changes in real exchange rates, lead to politically awkward realignments of trade, and cause recession for one or more players in the game. If such a hard landing is likely, then policymakers face the challenge of devising suitable countermeasures.

\footnotetext{
${ }^{1}$ On the source of this quotation, see the comment by John Helliwell.

${ }^{2}$ For Warsh on Wolf see http://www.economicprincipals.com/issues/05.04.10.html. For the Wolf forum see http://www.ftblogs.typepad.com/martin_wolf/. For up to the minute discussions see http://www.rgemonitor.com/blog/setser/. For a recent overview, see Eichengreen (2006).
} 
Confronting these two questions, what insights can we take from the past?

\section{Summary}

To summarize our findings, on the persistence of privilege we find:

- Among G7 countries today, the United States is not unique in being able to enjoy a "privilege" in the form of higher yields earned on external assets relative to yields paid on external liabilities. For the U.S. this has been worth about $0.5 \%$ of GDP to the U.S. in the years 1981 to 2003. Similar privileges are detectable for Japan and the U.K. France and Germany appear to have no privilege. Canada and Italy have negative privilege, or penalty.

○ In the years 1870-1913, the previous financial hegemon, Britain, enjoyed a similar yield privilege, also amounting to about $0.5 \%$ of GDP.

- Measured as a differential in rates of yield, the U.S. privilege has been steadily declining since the $1960 \mathrm{~s}$, when it stood at around 3\% per annum on all capital. It is now close to $1 \%$ per annum. Indirect measures may differ, and even the direct measures are subject to error. But if this trend continues, the U.S. will lose its privilege.

- Direct and indirect evidence on rates of yield for Britain in the past also suggests small and declining rates of yield privilege from the 1870s to 1910s, a similar pattern.

○ For both the U.S. now and Britain then, declining rate of yield privilege meant that for a given leverage and a given composition of assets and liabilities, the income due to privilege (as a fraction of GDP) would have to shrink. In part this was offset either by expanding leverage (in the U.S case today) or by shifting composition to riskier assets with higher returns (in both cases). These shifts may not be able to proceed without limit.

○ It is often suggested that the U.S. might lose privilege if the net debt position grows too large. We find that rate of yield privilege has been correlated with the deterioration of the net external asset position in the postwar era.

- In the historical British case, leverage and indebtedness were not an issue. British net external assets roughly equaled gross external assets, and Britain became a very large net creditor. But a net credit position did not preclude a loss of privilege, suggesting that even if the U.S. could reverse its net debt position, this would not protect its privilege automatically.

- Rather, British experience suggests that over time, financial hegemons operating in a globalizing world face other pressures that squeeze privilege. Emerging markets mature and offer less outlandish risk-reward combinations, so the benefit of being a "loan shark" diminishes; the world becomes less risky as a whole; at the same time other rival financial centers emerge which can compete for lucrative business with the financial pioneer.

- Most of these perspectives bode ill for the persistence of privilege. But if we add capital gains to yields we can estimate a total return privilege for the U.S. According to indirect estimates, total return privilege has risen since the 1960s. It also appears to have been steady in the 1980s and 1990s. Growing valuation effects have offset falling yield differentials, keeping up a total return privilege. It is unclear what mechanisms are driving these opposing trends. 
- Looking at indirect evidence on total returns on the U.K. domestic and foreign portfolio 1870-1913, we also find a total return differential, but one that is very volatile over successive decades, and with very little systematic privilege overall.

- The large capital gains earned by the U.S. in the last 10 to 15 years are due to neither sustained price effects nor sustained exchange rate effects, both of which are close to zero on average; the effect is largely due to "other" capital gains. These remain a mystery, and until we understand them better, simple extrapolation of these trends may be ill advised.

On adjustment we examine the behavior of current accounts and the processes associated with current account reversals for a broad sample of countries between 1880 and 1913 .

We attempt to verify whether there are any differences between the capital exporters like Britain, France, Germany, and the Netherlands, other core countries that import capital, areas that had recently been settled, also known as British offshoots (i.e., Australia, Canada, New Zealand and the United States), and less developed peripheral nations. Throughout we compare our findings to those from Edwards (2004) from the thirty years between 1970 and 2001.

In particular we look at: summary statistics regarding the size of current accounts and incidence of reversals; the ability to sustain current account deficits or surpluses; connections between current account reversals, exchange rate movements and financial crises; patterns of movement of macroeconomic aggregates in the wake of large current account reversals including the growth effects of reversals.

○ We find that more developed countries and the offshoots were able to run higher current account deficits more persistently, and that these countries had very different patterns of adjustment.

- In particular their current account reversals were generally associated with smaller real exchange rate fluctuations and less adjustment in the government surplus.

- Overall, we do not find overwhelming evidence that current account reversals had negative consequences for the aggregate growth of income per capita in the core or periphery. (Although many reversals involved serious crises that surely did have major distributional impacts.)

- Moreover, we are able to test some modern hypotheses with the historical data in ways that have not previously been done. We assess whether openness to international trade, financial and institutional development and currency mismatches played a role in adjustment.

- We find little evidence that currency mismatches, openness to international trade or the level of institutional and financial sophistication (proxied very roughly by higher income per capita) altered the severity of output losses associated with reversals in the nineteenth century.

- Nevertheless we do find some evidence that core Western European countries and the offshoots had lower growth losses in the adjustment process. Some countries even managed to see income rising in the face of reversals because previous investment was so productive. This offsets the negative growth experiences of other countries in the periphery leading to the finding that current account reversals were not systematically associated with output losses in this period. 


\section{Minimizing Adjustment: Are We Losing Our Marbles?}

As has been noted frequently in current and past debates, some countries may enjoy a special "privilege" - an excess return on assets relative to liabilities-allowing them to sustain larger trade deficits in equilibrium. For example, if all borrowing occurs at a constant world interest rate, then, absent default or other forms of capital gains, the long run budget constraint would require a net debtor like the U.S. to run future surpluses to extinguish the debt, requiring a large trade balance improvement. But if a debtor can earn investment income surpluses even as a net debtor, as the U.S. has, then the required degree of trade balance adjustment is mitigated.

Of course, this kind of scenario can cause umbrage among the creditors: creditors in the rest of the world are "winners" in a mercantilist sense (they run persistent net trade surpluses) but gain nothing from it as they give back (as net investment income flows) their "marbles" to the "loser," in Jacques Rueff's memorable terminology. Rueff and his colleagues were bothered by the U.S. ability to use this strategy during the Bretton Woods era (Despres, Kindleberger, and Salant 1966). French irritation found expression in Valery Giscard d'Eistang's much-misattributed reference to "exorbitant privilege" (Gourinchas and Rey forthcoming).

Why do these seemingly esoteric debates over return differentials matter so much? The differentials may seem small at first, and their contribution to overall flows rather minimal, but it turns out that even small changes in the assumptions about the future path of these differentials can be the difference between seemingly manageable and seemingly disastrous paths of future national indebtedness. Or, put another way, they can be the difference between a scenario in which drastic adjustment is needed, and one where only a minor correction is required. How can small differentials make such a big difference? The reason is simple-compounding small differences for a long time can make a huge difference to outcomes further down the road.

In pioneering contributions, Lane and Milesi Ferretti (2003, 2004, 2005ab), confronted the important question as to how external wealth evolves and how adjustment takes place. Their data since the 1970s provides important evidence on this subject, and an even longer run perspective on the postwar U.S. experience will be afforded by the soon-to-be released data of Gourinchas and Rey (forthcoming). More recently, as global imbalances have grown, a wave of policy analysis has followed these leads and has focused on the trends evident in the U.S. balance of payments. For example, in a comparative study of several models that project future imbalances and U.S. external wealth, we find the following (Kitchen 2006, Table 1; based on Roubini and Setser 2004; Higgins et al. 2005; Cline 2005):

○ In "optimistic" scenarios where the U.S. continues to enjoy favorable differentials in its favor with respect to income yields on FDI (500 basis points) and capital gains on all forms of external wealth (200 basis points), then by 2016 the U.S. net international investment position is likely to have a net debt in the range of minus $40 \%$ to minus $60 \%$ of GDP, with an income balance between $-1.5 \%$ and $+0.2 \%$ of GDP. The current account might then be about $-4 \%$ to $-5 \%$ of GDP.

- In "pessimistic" scenarios, all else equal, where privilege disappears and these differentials vanish, the U.S. may end up with an external position in excess of - 
$100 \%$ of GDP, and an income balance between $-3 \%$ and $-7.2 \%$. The current account might then be about $-10 \%$ to $-15 \%$ of GDP.

The range of these estimates depends on various other assumptions in the models studied, such as the speed at which the trade balance improves, and they assume that all imbalances are accommodated by financing from the rest of the world. Still, the numbers are illustrative only, and the point is this: whether privileges persist or not will make a big difference to outcomes in the future, having the potential to double or triple our net debt position and our income payments to the rest of the world in ten years' time.

So privileges are worth worrying about, and the realization that they may prove ephemeral is increasingly a cause for concern. Despite past trends, Geithner (2006) warns that "nevertheless, going forward, the scope for positive net factor payments from abroad and sizeable valuation effects is limited". Should we worry? Or, to reframe the question as Rueff might have said: will the United States lose its marbles? For suggestive evidence, we compare past and present experience.

\section{Measuring Privilege}

We examine four ways of thinking about "privilege." Suppose a country has external assets $A$, external liabilities $L$, and a net foreign asset position $N F A=A-L$ (all at the end of the previous year). In the current year, the country can earn an investment income flow that exceeds what would be predicted based on the world average rate of yield $r$ if its rate of yield on assets is higher $\left(r_{A}>r\right)$ or its rate of yield on liabilities lower $\left(r_{L}<r\right)$ than the world average, implying that net property income from abroad (NPIA) is

$$
\begin{gathered}
N P I A=r_{A} A-r_{L} L=[\underbrace{\left(r_{A}-r\right)}_{\begin{array}{c}
\text { rate of yield } \\
\text { privileg on assets } \\
\text { if > }>0
\end{array}} A+\underbrace{\left(r-r_{L}\right)}_{\begin{array}{c}
\text { rate of yield } \\
\text { privilege on liabilites } \\
\text { if }>0
\end{array}} L]+r(A-L) \\
>r(A-L)=\underbrace{r N F A}_{\begin{array}{c}
\text { NPA in the case } \\
\text { of zero privilege }
\end{array}}
\end{gathered}
$$

Scaling by $G D P$ we may write

$$
\frac{N P I A}{G D P}=r\left[\frac{N F A}{G D P}\right]+\underbrace{\left[\left(r_{A}-r\right) \frac{A}{G D P}-\left(r_{L}-r\right) \frac{L}{G D P}\right]}_{\substack{\text { yield privilege } \\ \text { as \% of GDP }}} .
$$

The term in brackets represents the yield privilege, measured as a fraction of GDP (say, in percent). It arises whenever there is a privilege in the form of rate of yields, that is whenever $r_{A}>r$ or $r_{L}<r$.

These yield privileges matter because they affect a country's wealth in the long run, and hence the adjustments necessary to satisfy the long run budget constraint. They 
show up in the current account CA since they are part of NPIA, which is one component of NFIA or net factor income from abroad (the so-called income account). ${ }^{3}$

As an accounting identity, the change in external wealth $W$ can be disaggregated into earnings on the trade balance $T B$, plus unilateral transfers $N U T$, plus net labor income from abroad NLIA, plus net property income from abroad NPIA, plus capital gains $K G$. The last two items can then be thought of as the total returns on external wealth, as follows:

$$
\begin{aligned}
\Delta W= & \underbrace{-F A}_{\begin{array}{c}
\text { net import of assets } \\
\text { (-financial account) }
\end{array}}+\underbrace{K G}_{\begin{array}{c}
\text { capital gains on } \\
\text { external assets and liabilities }
\end{array}}=\underbrace{C A+K A}_{\begin{array}{c}
-F A \\
\text { (BOP identity) }
\end{array}}+K G \\
& =\underbrace{T B+N+(N L I A+N P I A)+N U T}_{\text {CA definition }}+K A+K G \\
& =T B+\underbrace{N U T+K A}_{\text {transfers }}+\underbrace{N L I A}_{\text {net labor income }}+\underbrace{\left(r_{A} A-r_{L} L\right)}_{\text {net property income }}+\underbrace{\left(\gamma_{A} A-\gamma_{L} L\right)}_{\text {capital gains }} \\
& =T B+N U T+N L I A+K A+\left(\rho_{A} A-\rho_{L} L\right)
\end{aligned}
$$

where $r$ denotes yields, $\gamma$ denotes capital gains and $\rho$ denotes total returns (whether for assets and liabilities, as indicated by subscripts).

Thus, setting aside the first three BOP items in the last equation (or treating them as exogenous), the evolution of external wealth is critically affected by the total rates of return (rates of yield plus rates of capital gains) on assets and liabilities. The higher are the "privileges" (in yields or capital gains), the larger is the deficit that can be run on the trade balance in the long run, all else equal-and, hence, the smaller is the adjustment needed for a country that is temporarily running a trade deficit at a larger non-sustainable level.

We can use many approaches to explore these effects. Several have been proposed in the extant literature. All of these approaches are closely related to one another, so we need to pause and take stock.

1. Naive comparison of income flow and asset position. This is a simple way to illustrate privilege. Following equation (1) we can do a simple bivariate regression of $y=N P I A / G D P$ on $x=N F A / G D P$. The slope is an estimate of $r$ and the intercept an estimate of the yield privilege term in brackets. The relationship can also be seen using an $x-y$ scatterplot. Creditors with interest receipts sit in the positive quadrant; debtors with payments in the negative quadrant; in the other quadrants we find the paradoxical cases of debtors with receipts and creditors making payments. If an observation sits well above (or below) the diagonal with slope $r$ through the origin, then we can say the country has a privilege (or penalty). We use this method as a simple descriptive tool in this paper, since the relevant data are widely available for past and present periods. ${ }^{4}$ This method

\footnotetext{
${ }^{3}$ Due to data restrictions, as a first approximation, we shall sometimes treat net labor income from abroad NLIA as zero, in which case NPIA equals total net factor income from abroad, NFIA; this is necessary when using contemporary IFS data (which do not present separate data on labor income remittances).

${ }^{4}$ This method assumes the income balance data are reliable, although there are two concerns that for the U.S. these data may be biased by artificially high receipts (due to tax shifting to overseas affiliates) and
} 
makes certain assumptions that may not hold: the intercept need not be constant and changes over time might be detectable either due to changes in the balance sheet $(A$ and $L)$ or in the yield differentials. A fixed intercept only measures the "average" privilege. The slope may also change, for example, if there are changes in inflation, since the slope is a nominal not a real yield.

2. Direct calculation of privilege. Compute rates of yield directly. The rate of yield on assets equals investment income credits (from BOP data) divided by total assets (from NIIP data). The rate of yield on liabilities equals investment income debits (from BOP data) divided by total liabilities (from NIIP data). ${ }^{5}$ This method can be applied to disaggregated asset classes when disaggregated data on income flows and positions are available. For example, disaggregation shows that the current U.S. yield privilege is driven by FDI yield differentials (Higgins et al. 2005). This method can also be extended to include capital gains when capital gains data are available. A leading example is Kitchen (2006) using current U.S. data. He finds a large total return privilege in recent years, partly due to yields and partly due to capital gains of unidentifiable origin. The method cannot be applied historically in the aggregate because gross position data are not available for the past; however, microeconomic data do permit some comparisons.

3. Indirect calculation of privilege. Ignore reported income flow data and use market data to compute returns for synthetic portfolios. These should match actual portfolios as closely as possible, e.g. by using portfolio-weighted stock market data. This method does not suffer, then, from errors in investment flow data (e.g., the accrual basis used for interest flows; Buiter 2006). It should also avoid problems of underreporting of investment income (the likely major source of the global current account deficit). However, it also relies on assumptions that the weights are correct and that returns and valuation changes derived from stock and bond indices track those of the actual portfolio. The most fragile calculations are the imputations of returns to FDI (especially privately held companies). Subject to these caveats, and after a lot of work, imputed yields and imputed capital gains on synthetic asset and liability positions can be estimated. A leading example is Gourinchas and Rey (forthcoming), who find that the U.S. has enjoyed large and growing privilege in total returns since the 1950s. Some of this is due to a growing return differential in all asset classes, and some is due to a composition shift toward higher return (risky) assets.

artificially low payments (due to underreporting of income on foreign FDI in the U.S.). The first point need not be an issue for adjustment if this is achieved via transfer pricing, since there is then an offsetting item in the trade balance, as noted by Philip Lane and others; the second point may be an issue, since the U.S. income position is likely being misreported, as noted by Daniel Gros and others (see http://www.rgemonitor.com/blog/setser/). Admittedly there may be other biases in the income balance. Globally, IFS data for 2003 show the world has a deficit on trade of $1.6 \%$ of reported imports (if this is underreporting on the import side it is likely trade tax evasion), but the deficit on the income balance is $6.8 \%$ of reported credits, suggesting a bigger problem with underreported foreign income. If such a bias applied to the U.S. in 2004, it would add about $\$ 25$ billion to U.S. NFIA, a rough doubling.

${ }_{5}$ As with the previous method, this method assumes the income flow data are correct. But it also requires that the position data be correct, and here there is even greater controversy. Since NIIP data are usually built up from survey reports, the accuracy and consistency of the reporting is open to question. As we shall see later in this section, there are large changes in NIIP data from year to year that are simply not accounted for by financial flows, exchange rate changes, and price changes. 
4. Privilege-Adjusted Net Foreign Asset Position Not a new concept: this is just a reworking of method 2. Instead of focusing on the return differentials, this method replaces the official (market value) measures of assets $A$ and liabilities $L$, with adjusted measures $A^{*}$ and $L^{*}$ so that under a uniform world rate of yield $r$ the modified positions yield the actual income flows seen, that is, $r_{A} A=r A^{*}$ and $r_{L} L=r L^{*}$. Hence, in cases of privilege, where $r_{A}>r$ or $r_{L}<r$, external assets increase, and liabilities shrink, $A^{*}=r_{A} A / r>A$ and $L^{*}=r_{L} L / r<L$. This method can also be applied to disaggregated asset classes. This method does not consider capital gains (i.e., total returns), though in principle it could be extended in that way. This method was proposed by Hausmann and Sturzenegger (2006), who arbitrarily set $r$ equal to 5\%. They find that whereas the conventional NFA position of the U.S. has deteriorated, the adjusted NFA position, NFA* $=A^{*}-L^{*}$ reveals virtually no change since the 1970s. Given that the FDI component contains all of the yield differential, inevitably it is in the FDI component that almost all of the adjustments occur en route to $\mathrm{A}^{*}$ and $\mathrm{L}^{*}$.

Due to a combination of theoretical and empirical concerns, none of these methods proves ideal in practice, but taken together they offer corroborating evidence when the underlying data are fragmentary. ${ }^{6}$

\section{Some Simple Estimates of Privilege}

Following method 1, we begin with the simplest of comparative exercises. Looking across time and space, we see whether countries are able to earn more on the investment income account than would be predicted under an assumption of a uniform world real interest rate. To do this we run a regression

$$
\frac{N P I A}{G D P}=\beta\left[\frac{N F A}{G D P}\right]+\alpha_{i}+u_{i t}
$$

which is the econometric analog of equation (1).

For the time being we assume the slope is constant across any sample (we allow this to vary later); we also assume the intercept is constant over time, but we allow it to vary across countries. The slope is an estimate of $r$ in equation (1) and the intercepts are estimates of a country's "average" yield privilege as a fraction of GDP.

\footnotetext{
${ }^{6}$ Method 4, the most recent to be proposed by Hausmann and Sturzenegger (2006), has probably attracted the most controversy of the four methods. Opinions are divided on the so-called "dark matter" hypothesis. It is uncontroversial that the adjusted NFA positions are nothing more than a different way of looking at yield privilege (as the formulae show, there is a direct mapping from yield differentials and gross positions to NFA*). What is still disputed is whether these differentials are an expression of unmeasured exports such as liquidity services, insurance services, or "know-how" (see, e.g. Buiter 2006; or Brad Setser's blog). Hausmann and Sturzenegger (2006) do find a strong correlation between their "dark matter" measure (the gap between NFA* and NFA) and FDI, which is consistent with other research identifying FDI as the main source of yield differentials (Cline 2005; Higgins et al. 2005; Kitchen 2006). Disaggregation can illuminate the sources of differentials and how these change over time, but in this paper we look only at aggregate yield differentials and use the adjusted NFA positions solely for that purpose.
} 
Figure 1 shows a simple example of this method for the United States using data for 1981-2003. The slope is $2.3 \%$, a measure of the rate of yield. The intercept is $0.5 \%$ of GDP, a sign that the U.S. enjoyed an average level of privilege equal to about $0.5 \%$ of GDP over two decades. The details of the corresponding regression (3) appear in Table 1, panel (a), column 1. The result is not surprising: since the mid 1980s the U.S. has been a net debtor but after two decades it has only just reached a position where the investment income balance is about to turn negative: the U.S. data points for this period sit in the paradoxical zone in the upper-left quadrant of the scatterplot. The points line up along the line of best fit. One way to see the extent of privilege is to plot the line of best fit and a parallel line through the origin. The vertical distance between the two equals the "privilege" or intercept which is worth on average $0.5 \%$ of GDP.

Having noted the existence and extent of U.S. privilege, we focus on two comparative questions: Is this privilege unique by contemporary standards? And is it unique by historical standards? Some answers are shown in the remainder of Table 1 and in Figures 2 and 3.

Most conjectures about the source of privilege tend to focus on certain characteristics of the privileged nation. Hegemony explanations tend to stress economic or military strength. Institutional "safe haven" explanations stress a country's record of property rights (security from expropriation risk) and economic stability (security from inflation or other risks). Purely economic explanations would stress the special features of a country's financial or investment sector to provide "know how" or other unobservable but valuable services. A country's position as a financial center could also count in cases where concentration and size matter, for example, in the provision of market depth and liquidity. Reserve currency status also might matter. Where else but the U.S. might such privileges be detected?

As a first step we think it natural to look at a group of other large, advanced countries: the G7. Table 1, column 3 reports regression (3) for the G7, including the U.S. Unreported results for the G7 excluding the U.S., and for each country individually yield qualitatively similar findings. Compared to column 1, the slope reveals a world rate of yield of $2.5 \%$. But the intercepts are revealing. The U.S. again has a privilege, still $0.5 \%$ of GDP. So too do Japan and the United Kingdom. ${ }^{7}$ France and Germany have intercepts that are slightly positive ( $0.2 \%$ of GDP) but not statistically significant. Canada and Italy have negative intercepts, a sign that they are paying penalties that are statistically significant, respectively, $-2.5 \%$ and $-0.8 \%$ of GDP.

To illustrate these patterns Figure 2 shows a scatterplot using the same axes as Figure 1. A diagonal line through the origin is plotted with a slope equal to the estimated common value of $r$. For countries with a zero intercept, all points should sit on this line, which we might call the "neutral line" where there is neither penalty nor privilege. Points above this line correspond the privilege, those below to penalty, using our terminology. To permit comparison with Figure 1, the U.S. points in Figure 2 are picked out with an " $x$ " symbol. All of the U.S. points sit in a zone well above the neutral line. Only a fraction of the non-U.S. points sit in that zone, and many are close to or below the diagonal.

To add a little more detail to this description, panel (b) of Table 1 computes an indicator variable based on the regressions in panel (a). We compare the distance between

\footnotetext{
${ }^{7}$ The existence of such a privilege for the U.K. was recently noted by Nickell (2006).
} 
each point and the "neutral line" and compare it to the standard deviation of the fitted value. If the point is 2 standard deviations or more above the neutral line we label this country-year observation as being in the privilege zone; if it is 2 standard deviations below we label it as in the penalty zone. ${ }^{8}$

Columns 1 and 3 confirm that the U.S. has been in the privilege zone $100 \%$ of the time. In the rest of the G7, more time is spent in the neutral or penalty zone. Japan is $94 \%$ in the privilege zone, and the U.K. 76\%. France and Germany are there 56\% and 66\% of the time, respectively, but also spend a nontrivial amount of time in the penalty zone. Canada and Italy spend $2 / 3$ of their time in the penalty zone

To sum up, among the G7, privilege can be often be found outside the U.S. in both Japan and the U.K. Although not hegemonic powers like the U.S., these two countries are both financial centers and issue important global currencies.

What about historical precedents? Several conjectures in the current debate lead us to focus on the experience of Britain in the 1870-1913 period as a case study of privilege in the past. Britain was the hegemonic power of its time, held a global empire, and despite the rise of the U.S. and other competitors was still a leading industrial power. It was also, famously, a "banker to the world" before that term was gradually applied more to the U.S. as the years after 1914 went by. Sterling was the most important key currency of that time. How relevant is a U.S.-U.K. comparison for this paper? Many commentators have speculated on the similarities between the financial "privilege" that Britain enjoyed in the late nineteenth century and that of the United States in the postwar period, noting the ways in which this relaxed the British long-run budget constraint and eased adjustment; for example:

...foreigners effectively giving Britain interest free loans by holding sterling and by sterling's enhancement of world liquidity...by analogy with the role of the U.S. dollar after 1945, the key currency system contained the seeds of its own destruction....British industry had to export less in order to buy a given quantity of imports than if sterling had not been a reserve currency....The adjustments of prices in the British economy and of the industrial structure, necessary to maintain a balance of payments equilibrium, were reduced....If Britain had been forced to adjust faster the structure of her industry, not only would the eventual adjustment have been less wrenching, but the rate of industrial growth in the late 19th century might have been higher. (Foreman Peck 1995, p. 168)

So let us examine the empirical evidence for British privilege. Table 1, column 5 repeats our regression analysis for the U.K. in the years 1870 to 1913, the so-called "age of high imperialism" when Britain rose to pre-eminence as the a center of global finance. The results are quite similar to those seen for the contemporary United States in column 1. A slope of $4 \%$ represents the estimated rate of yield. An intercept of $0.6 \%$ of GDP suggests that the U.K. did enjoy some privilege. Panel (b) indicates that the U.K. was in the privilege zone $80 \%$ of the time, and otherwise in the neutral zone. The corresponding scatter appears in Figure 3.

However, two key differences, and one similarity, stand out when comparing Britain then and the U.S. now.

\footnotetext{
${ }^{8}$ The missing category, within 2 standard deviations of the diagonal is the neutral zone.
} 
First, as a fraction of GDP, British privilege was only marginally statistically significant (at the $10 \%$ level not the $5 \%$ level).

Second, as is apparent from a brief glance at Figures 1 and 3, Britain was in a very different position to the U.S. today. Britain was a large net creditor: NFA was positive and increasing, and approaching $200 \%$ of GDP by period's end. But today the U.S. is a large net debtor, with NFA falling below zero in the early 1980s and nearing $30 \%$ of GDP today. The U.K. inhabited the "normal" upper-right quadrant in Figure 3, but the U.S. inhabited the "paradoxical" upper-left quadrant in Figure 1.

Third, we note that the extent of the privilege enjoyed by the U.K. then and the U.S. now was quite volatile, measured as a fraction of GDP. Treating the privilege as the gap between the actual observed NFIA/GDP and that predicted by the fitted line constrained to pass through the origin, the implied measures of privilege are shown in Figure 4. Both figures show a distinct "W" shape.

To use the terminology of Higgins et al. (2005), both of these countries have at times enjoyed a "series of fortunate events" taking the investment income balance far above trend in certain periods. In the early 1870 s, U.K. returns were high after a loan boom, before a wave of crises and defaults hit emerging markets, and investment returns fell. The same pattern was witnessed in the 1890s, before and after the Baring crash. This highlights the possibility of recurring "peso problems" (Buiter 2005): risky foreign assets may generate supranormal returns for a time, but the trends may not be sustained.

In the case of the United States, some of the same factors are possibly at work, along with exchange rate effects. Net income yields were low during strong dollar periods (mid 1980s, late 1990s), and these were also times of default in many emerging market bonds. The recent uptick in privilege for the U.S. in 2000-03 echoes that for the U.K. in 1905-13. But if the clock had been stopped earlier in each case-1905 for U.K. and 2000 for U.S. - then an unmistakable downward trend in privilege would be evident.

Before proceeding it should be noted that in the regressions reported so far we have been analyzing a nominal yield $r$ based on the slope estimates in regression (3). Should nominal yields be stable? This is, for example, the implicit assumption of Hausmann and Sturzenegger (2006), who use a constant arbitrary 5\% discount rate, that is, a "price-earnings" ratio of 20 for all assets. An alternative approach would recognize that $r$ is a rate of nominal yield, and that it might fluctuate systematically with the rate of inflation $\pi$. In this case we might be better off estimating a variant of equation (3):

$$
\frac{N P I A}{G D P}=\tilde{\beta}\left[\frac{N F A}{G D P}\right]+\theta\left[\pi \frac{N F A}{G D P}\right]+\alpha_{i}+u_{i t} .
$$

If the Fisher effect holds for all assets and their yields, then the coefficient $\theta$ should equal unity. But this may not be the case in practice. If loans payments are tied to a floating rate of interest, the pass through of inflation to yields will depend on the speed of market adjustment and the accuracy of expectations. If fixed income yields are at a fixed interest rate, no change in yields will occur. In principle, this ought to be resolved by changes in the market value of the underlying debt, but from an empirical standpoint it is doubtful that all such loans and debts are properly revalued in the data. Thus, we do not impose a unity restriction on $\theta$ (for if we did, it would be rejected) when we estimate (4) in columns 2, 4, and 6 of Table 1, panel (a). The bottom line is unchanged, however. The 
measures of privilege by country are only slightly affected when this simple inflation adjustment is carried out, as all the findings based on columns 1,3 , and 5 are valid.

The lesson from these simple calculations is that the U.S. enjoyment of privilege today is not unprecedented by contemporary standards. We even find evidence of an historical precedent in the case of Britain during the first age of globalization. In the following sections we look at some of the details that lie behind these simple comparisons, trying to understand what is and was going on in the past for the British case and in the present for the U.S. case (with the G7 still as a backdrop).

\section{Disappearing Privilege Then and Now?}

We first turn to the trend in privilege over time. The privilege term in (1) need not be constant, of course. Two factors operate to affect the size of this term. First, the differential between rates of yield on assets and liabilities: the bigger the rate of yield differential, the bigger the privilege term. Second, leverage: if there are yield differentials, they can be exploited by enlarging the size of the nation's balance sheet, increasing $A$ and/or $L$.

The implication is that if a country faces declining yield differentials on its portfolio, then to preserve its privilege one of two things must happen.

First, there might be a reweighting of the country's asset and liability portfolios that raises aggregate differentials via composition effects. For example, if debt and fixed income assets yield less than equity or FDI, a country will earn more if it sells foreigners less high yield home equity and more low yield home debt. A country also earns more if it purchases more high yield foreign equity and less low yield debt. It has been suggested, for example, that recent political maneuvers to block foreign takeovers in a number of countries could reflect, in part, this sort of concern.

Second, an increase leverage may occur which helps offset a fall in differentials. For example, if the yield differentials are cut in half, then the same amount of investment income can be attained by doubling the size of the national balance sheet, that is by doubling $A$ and $L$.

These two kinds of responses would show up in macroeconomic aggregates but would be a manifestation of microeconomic decisions by investors. Either way, each investor, and in aggregate the country, takes on more risk, either by engaging in a quest for yield or by ramping up leverage.

The interplay between these two forces could be of importance both in the past and the present. For example, we will show below that rate of yield differentials appear to have shrunk for the two hegemons in the periods we study: Britain 1870-1913 and U.S. in the postwar period. This appears to have been true in the aggregate portfolios, even allowing for the fact that both countries, in the search for yield, are thought to have reweighted their portfolios toward riskier and higher yielding equity assets over time.

In Table 2 we repeat the analysis of Table 1 for the U.S. now and the U.K. then but include an "early" indicator to test for an early period of "high privilege" in the sample (pre-1880 and pre-1992). We find evidence that U.K. and U.S. privilege, as a fraction of GDP, was much higher in the early years compared to the late years. For the U.K., privilege was $0.9 \%$ (of GDP) higher pre-1890, a difference significant at the $1 \%$ level. For the U.S. privilege was $0.2 \%$ higher pre-1992, but the difference is of borderline 
significance using a $10 \%$ (two-tailed) test. These results offer the first suggestion that yield privilege can be something difficult to sustain. What lies behind these results?

We begin with the historical example of the British. An important fact to remember is that we do not possess gross asset and liability positions for this period, so direct calculation of the privilege term in (1) and its components is not feasible, ruling out method 2. Instead we can turn to methods 3 and 4: look at market yield data on portfolio assets, or perform an adjusted NFA calculation.

We begin with the simpler adjusted NFA approach. We employ an arbitrary $4 \%$ discount rate (cf Table 1) and infer the British adjusted NFA position. To do this we take the net investment income each year from 1870 to 1913 , multiply by 25 , and call this NFA*. We can compare this with NFA, the conventional measure of the net position derived by economic historians by accumulating the current account and adding it to some known absolute position data for a given benchmark year.

The result of this comparison is shown in Figure 5. We recall that Hausmann and Sturzenegger's NFA* is not a new concept-it is just another way of expressing yield differentials and the privilege associated with them. By implication, if these privileges are big, then NFA* should deviate very significantly from NFA - in a positive direction for a privileged country, and in a negative direction for a penalized country. ${ }^{9}$

In contrast to recent U.S. experience, Figure 5 shows no evidence of any substantial deviations from 1870 to 1913 . The two measures NFA* and NFA track each other very closely. Given the isomorphism between yield differentials and the size of the NFA adjustment, this finding gives an indirect test of the presence of yield differentials in the British case. Minimal or nonexistent differences between NFA and NFA* imply minimal or nonexistent British yield privilege.

Should we believe an indirect test? One reason for doubt is that the source data for the British investment income data series is rather conjectural. Imlah (1958, pp. 5964) had no records on actual investment income flows and instead imputed annual U.K. NFIA based on estimates - some might say educated guesses - about the rate of return on the British overseas portfolio. The rate was then applied to an estimate of the British NFA position, which was equally fragile, not least because it depended in part on cumulated NFIA as an element in cumulated CA (Imlah 1958, pp. 64-81). In other words, in the above calculations, all the indirect method does is reveal what Imlah thought the British rate of return on external assets was doing from year to year.

To probe further, we might like to get additional and more precise direct or indirect evidence on yields. Unfortunately, the direct method is impossible in the aggregate data, as noted, so the best hope right now is the indirect method 3. However, data limitations mean we cannot replicate Gourinchas and Rey (forthcoming) until we have yield and position data for the British portfolios or at least a large share of them. But fortunately we do have some more recent yield measures that ought to be more accurate than the Imlah (1958) conjectured yields.

\footnotetext{
${ }^{9}$ For example, when Hausmann and Sturzenegger (2005) find that the U.S. path for NFA* is level whilst the path for NFA plunges precipitously, they are merely restating in a different metric what Gourinchas and Rey (2005) called the "famous observation that the large increase in U.S. net liabilities to the rest of the world has not been accompanied by a commensurate increase in net income payments"; that is to say, investment income balances have not lined up with the net asset position, so the privilege "intercept" is positive in (1), as in Figure 1.
} 
Realized rates of profit for a sample of British companies at home and abroad were computed by Davis and Huttenback (1986). Figure 6 summarizes their important findings for the 1870 to 1913 period. In the early years, Britain enjoyed very high returns on its overseas investments, notably its investments in the Empire, something the authors attribute to Britain's role as a "pioneer" in the business of foreign investment in the 1870s and 1880s. However, these high returns soon evaporated. By 1900 and later, foreign nonempire investment, empire investments and domestic investments were all showing similar rates of yield. ${ }^{10}$

Concerning government debt, we know that ex ante yields experienced dramatic convergence from 1870 to 1913 , as shown in Figure 7. We recall again the "peso problem"; ex post yields were surely never so high and some of this convergence was probably due to the diminution of risk premia. We might expect ex post returns to have converged rather less.

From this fragmentary evidence-the lack of privilege suggested by the adjusted NFA calculation and the suggestive evidence on yield differentials-we might conclude that the British faced declining yield differentials even when at the heights of their economic and military power, and even when London stood as the world's undisputed financial center, a locus of investment "know how," and an unimpeachable "safe haven." True, the British did expand their balance sheet dramatically (as we saw in Figure 3), and they did shift to more risky assets in the private sector and in nonempire emerging markets as time went by. But apparently this was not enough to deliver a strong and persistent measure of privilege relative to GDP: as we saw in Table 1, the British intercept was positive but only of weak statistical significance.

One theme that must be re-emphasized throughout this paper is that naive extrapolation from the past is ill advised, whether the past is the last 20 years or the period 1870-1913. Still, the British experience in the late nineteenth century cautions against ever assuming that privilege is automatically perpetuated. Perhaps the British did have some initial advantages in the 1870 s and 1880s that delivered privilege. But this did not last. Other countries like France, Germany and later the U.S. entered the fray to compete with Britain in overseas investment, and the British share of world overseas assets shrank from 78\% to 50\% from 1855 to 1914 (Obstfeld and Taylor 2004). Britain may have lost its "pioneer" advantages in some markets and in other countries risk premia may have fallen as the institutional environment improved.

With those cautionary words in mind we turn to the U.S. experience since the 1960s. Now, the direct method 2 is feasible and we need not beat about the bush with indirect evidence. Figure 8 illustrates the bottom line regarding rates of yield using BEA data. Rates of yield on assets and liabilities (in nominal dollar terms) obviously peaked in the late 1970s and early 1980s as inflation reached its postwar peak. But the important issue for us is not the level of these rates of yield, but the differential-which, fortunately, is naturally purged of any effects of inflation.

The yield differential appears at the bottom of Figure 8. Its trend is unmistakably downward. We can also see that U.S. yield differentials tend to rise and fall in line with the strength of the dollar: the dollar value of yields on overseas assets tends to be low (relative to the yield paid on liabilities) when the dollar is strong. In the mid 1980s and

\footnotetext{
${ }^{10}$ As explained, Davis and Huttenback $(1986,84)$, these measures do not include capital gains, so in this context they are termed rates of yield, in contrast to rates of total return that include capital gains.
} 
again in the mid 1990s the U.S. yield differential is low. This is not surprising, when there are deviations from PPP in the short run. A good deal of foreign investment income is denominated in local currency, and its dollar value will be depressed when the dollar is strong.

Figure 8 helps us understand the indignant stance of the French in the 1960s: at that time the U.S. yield differential was a whopping $3 \%$ or 300bps. Since 1975 it has barely risen above $2 \%$. Since 1995 , it has averaged about $1.5 \%$, reaching a low of under $1 \%$ or $100 \mathrm{bps}$ in 1999 . Over this period the rate of yield privilege has fallen by about 200 bps. Many fewer marbles are being returned these days, compared to how the game was played under Bretton Woods. ${ }^{11}$

Table 3 and Figure 9 shows how the U.S. stacks up against the rest of the G7 where the yield differential is computed from 1981 onwards using a dataset that is comparable across countries. ${ }^{12}$ Table 3 shows that among the G7 countries, the U.S. has enjoyed a large and statistically significant rate of yield differential of about 167 basis points on average. But two other countries have enjoyed positive and significant yield differentials: Japan (112 bps) and, ironically, France (80 bps). Italy (-52 bps) and Canada $(-139 \mathrm{bps})$ have had adverse rate of yield differentials. ${ }^{13}$

Figure 9 exposes the volatility of this differential over time and also reveals a trend: the U.S. began with quite high levels of privilege relative to the rest of the G7 (where on average, differentials have been about zero), but the trend over time has been an inexorable convergence of the U.S. yield differential towards zero. Regression analysis confirms that the U.S. yield differential has a negative and statistically significant time trend (in the G7, only the U.K. has enjoyed a positive and statistically significant time trend in this differential). Again, as in Figure 8, we see that the U.S. yield differential has been declining, with this trend only abating in periods when the dollar is weak.

Only time will tell, but the recent uptick in the differential in 2000-03 is the source of much controversy. A longer run perspective seems to indicate that although that uptick is there, the longer run trend is one of vanishing yield differentials or disappearing privilege, just as in the British case a century before.

\section{Maintaining Privilege via Leverage?}

At the start of this section we showed that the U.S. has managed to maintain a nontrivial "privilege" that has averaged about $0.5 \%$ of GDP over the last two decades. Close scrutiny of Figure 1 suggests that, relative to the fitted values, privilege relative to GDP has been fairly stable over the years, with a slight upward blip evident in the years after the millennium (the points furthest to the left on the scatterplot). This blip is largely driven by the aforementioned uptick in yield differentials observed in 2000-03.

\footnotetext{
${ }^{11}$ Another way of looking at this is to note that at the end of the period the nominal yield on assets was $4 \%$, and that on liabilities 3\%, which matches the ratio of 1.3 computed by Gourinchas and Rey (2005); but back in the 1960s, a time of comparable low inflation, the figures were about $3 \%$ and $6 \%$, a ratio of 2 .

${ }^{12}$ We use the IMF IFS for investment income data proxied by NFIA, and Lane and Milesi-Ferretti (2004) for data on external positions.

${ }^{13}$ There may be other countries outside the G7 that have enjoyed a yield privilege in recent times. For example, in an analysis of uncovered interest parity, Switzerland appears to have had a systematic negative risk premium with respect to OECD countries (Kugler and Weder 2005).
} 
Yet, notwithstanding a couple of such blips, we have also seen that over time U.S. yield differentials followed a downward trend since 1981. So, looking at equation (1), we reach the immediate conclusion that the U.S. has only been able to maintain its privilege as a fraction of GDP by raising its leverage to offset the diminution in yield differentials.

Figure 10 explores this mechanism further. Using BEA and U.S. Historical Statistics data back to the 1960s, we examine the actual path of the yield privilege as a fraction of GDP, and its counterfactual path under the assumption that rate of yield differentials had been constant at their average 1960s values throughout the period (about $300 \mathrm{bps})$. In the counterfactual, differentials would thus be much higher in later years than was actually seen. ${ }^{14}$

Figure 10 shows what we would expect. We know the U.S. has been increasing its leverage dramatically since the 1960s. If the U.S. balance sheets had expanded thus with constant 1960s average yield differentials over the entire period, then in 2003 the privilege, rather than being about $1 \%$ of GDP would have been about $2 \%$. Put another way, if leverage massively increases over several decades then it is not that reassuring when we find privilege merely holding steady as a fraction of GDP (Hausmann and Sturzenegger 2005). If yield differentials - the ultimate basis of the privilege- were stable, then privilege ought to have exploded relative to GDP, counterfactually, as in Figure 10. The reason they didn't is that the yield differentials are narrowing. From this perspective, U.S. privilege is disappearing.

When we focus on this trend, subject to the caveat about naive extrapolation, the outlook is surely less rosy, for two reasons. First, if the differential keeps shrinking, then astronomic and implausible explosions in leverage would be needed to maintain privilege at its current level as a fraction of GDP; if the differential reaches zero, privilege will vanish. Second, the 2000-03 blip may or may not be sustainable, and some or all of it is due to transitory effects-overseas earnings are boosted by a weakening dollar, there has been a tax amnesty, there have been low interest rates on debt liabilities, and so on (Higgins et al. 2005).

One might add a third observation. Correlation does not imply causation, but this shrinkage in the yield differential obviously does coincide with the United States sliding from a net creditor position to a net debtor position, as shown in Figure 12. If there is a causal link here, and differentials shrink as net debt increases, then a Laffer curve type of argument tells us that at some point the U.S. will reach (or may already have reached) a point of maximum privilege relative to GDP.

\section{Capital Gains}

The main focus so far has been on the yield differentials that underpin privilege in equation (1). However, the evolution of wealth is also affected by capital gains, as seen in equation (2). So even if a country suffers a decline in yield differentials it might be of no consequence for the long run budget constraint if it is offset by an increase in the capital gain differential; thus adjustment may be avoided if capital gains offset any change in yields.

The evidence on capital gains is even more fragile and fragmentary than that on investment income yields, but we make a few observations. Using indirect measures of

\footnotetext{
${ }^{14}$ For the purposes of the counterfactual, we attribute $50 \%$ of the difference in the yield differential to the yield on assets, and $50 \%$ to the yield on liabilities.
} 
total returns, Gourinchas and Rey (forthcoming) find evidence that U.S. total return differentials (for assets minus liabilities) may have grown in the post Bretton Woods period as compared to the Bretton Woods period. Given that the total return differential equals the yield differential plus the capital gain differential, this says the capital gain differentials must have grown enormously, since we know from the above that yield differentials have shrunk. If anything, the U.S. had a "penalty" on the capital gains differential in the Bretton Woods era, averaging about $-2 \%$ of GDP. Then, once the floating rate period began, the U.S. enjoyed positive valuation effects. It is tempting to infer that it was the breakdown of the dollar standard - and the ability of the U.S. to reap exchange-rate driven capital gains - that caused this shift. But as we shall see in a moment, the exchange rate channel seems weak. The data show that capital gains on external wealth moved in favor of the U.S. in every year until the turn of the millennium, at the height of the U.S. stock market. Capital gains were then zero or negative for several quarters.

Another perspective is presented by Kitchen (2006). He examined trends only since 1989 using direct BEA measures, and in that shorter window no firm time trends emerge, leading him to conclude that a positive $2 \%$ rate of capital gain differential in favor of the U.S. is the norm in recent years.

We would raise two questions here. First, if this differential is flat, will it offset a declining yield differential trend, should that continue? Obviously the answer is no, even if such a constant differential can be assumed to continue. Second, where are these capital gains coming from? This turns out to be a dark secret. Kitchen (2006) relates how the BEA classifies valuation effects as arising from three factors. First, "prices" (meaning changes in prices of assets in the currency of denomination). Second, "exchange rates" (this barely affects liabilities, but reflects changes in the dollar values of nondollar assets due to changes in currency values). Finally, "other."

It turns out that since 1989 the price component of capital gains has delivered a rate of return of about $1.5 \%$ on both external assets and liabilities: no differential there. Exchange rate changes have been zero on average (but large in some years). On average, the positive differential in the rate of capital gains on assets versus liabilities has been entirely due to the final mysterious "other" category: about 100bps on assets and 100bps on liabilities (with both in favor of the U.S. for a total differential of 200bps). What is "other"? Apparently "discussions with BEA staff indicate that the source of much of this 'other' valuation change is simply unidentified" (Kitchen 2006, 16), prompting Cline (2005) to call these gains "statistical 'manna from heaven." This inability to account for the source of the capital gains is quite worrying. We ought to feel slightly uneasy if we cannot really understand these gains, and we should feel very uneasy about the idea of extrapolating something we cannot understand. ${ }^{15}$

Notwithstanding the mystery surrounding the source capital gains, have they been enough to offset the declining U.S. yield differential? Table 4 and Figure 11 show that

\footnotetext{
${ }^{15}$ One possible source of these mysterious gains is simply mismeasurement. For example, the statistical discrepancy in the balance of payments is often quite large. As an accounting principle, it appears routine to fold this discrepancy into financial account (see e.g. Lane and Milesi-Ferretti 2004; Nickell 2006). This accounting implicitly treats the current account side as the fully reliable measure. In practice, this distribution of the error is unlikely to be correct. Since valuation effects are simply the difference between reported external wealth changes and (minus) the financial account, falsely attributing a part of the statistical discrepancy to the financial account will bias the measure of capital gains.
} 
they have. These figures repeat the format of Table 3 and Figure 8, but show total rate of return differentials for the G7, not just rate of yield differentials. The difference is just capital gains, and since the capital gains are a volatile measure (partly accounted for by nature, partly due to measurement error) these data have much higher variance. The bottom line is that switching to total rates of return places the U.S. in a unique position as the only privileged country among the G7.

Table 4 shows that among the G7 countries, the U.S. has enjoyed a large and statistically significant rate of total return differential of about 370 basis points on average. ${ }^{16}$ Of the U.S. total return differential, we have already seen that about $167 \mathrm{bps}$ was due to yields, so the remaining $203 \mathrm{bps}$ is due to capital gains. ${ }^{17}$ On average these two parts of the differential have played an almost equal role. But the trends of the two components are obviously different. The trend in the total return differential is flat (which is confirmed by regression analysis). But because Figure 8 showed that the rate of yield differential was closing, the result here implies that differential in the rate of capital gains must be widening.

It would be interesting to see how trends in capital gains (or total returns) evolved in the past for the case of Britain from 1870 and 1913. Unfortunately, limitations of the current historical macroeconomic data preclude any calculation of gross valuation effects with even the limited degree of precision we accept today. Imlah (1958, pp. 59-81) ignored capital gains entirely, and assumed that gains and losses roughly cancelled out. However, as with our earlier discussion of yields, we can make use of some more recent data based on samples of traded securities.

Edelstein (1982) has computed total returns for home and foreign portfolios of equity and debenture assets in the U.K. portfolio in the late nineteenth century. The summary data in Figure 12 suggest no discernible trend movement in the differential between home and foreign assets. Indeed, a noticeable differential is apparent only for debentures (including both government and private bonds and debt), suggesting that even as ex ante differentials converged ex post differentials were rather steady.

There is suggestive evidence here that Britain then, like the United States now, made a transition from "banker" to "venture capitalist" mode whereby returns to investors increasingly took the form of capital gains rather than yields. So the "good news" from the past for the U.S. position today is that such a transition is possible, although worryingly the U.S. data are provide us with no comprehension of where these gains originate. The "bad news" is that U.K. return differentials were quite volatile in the long run-a decade or so of large positive differentials can be followed by another decade with a large negative differential. Naive trend extrapolation is unwise.

\section{Summary: Privilege has its Memberships}

The United States has gradually become the world's largest debtor and the world's largest creditor over the last half century. Over that same period, official data show that the U.S. has earned higher yields (and higher total returns) on its external assets than the rest of the world has earned on U.S. external liabilities. Yet the rate of yield differential

\footnotetext{
${ }^{16}$ For all other countries, zero is within the $95 \%$ confidence interval, and mean total return differential range between at most +25 bps (U.K.) and -62 bps (Germany).

${ }^{17}$ This is presumably driven by those "other" capital gains identified by Kitchen (2006), who found a very similar 210 bps differential.
} 
has fallen, from 300bps in the early 1960s to maybe 150bps today. And if some of that remaining $150 \mathrm{bps}$ is due to understated income payments to foreigners, the gap today could in reality be nearing zero (Gros 2006).

It appears that expanding leverage has offset diminishing yield differentials to prop up "privilege" as a fraction of GDP. Yet the future extrapolation of this trend is doubtful: the net external position cannot trend up forever, and if the yield differential continues to trend down, no amount of leverage will help. At the present time a significant contribution from ill-defined capital gains is keeping up the U.S. measures of privilege, and more research will be required to verify and identify these mysterious additions to U.S. external wealth.

A century ago, Britain enjoyed a similar hegemonic position-economically as well as geopolitically. Britain also appeared to enjoy some modest privilege at times. But this privilege could not be sustained, even from a massive net credit position. International financial competition, the global quest for yield, and the maturing of emerging markets all put a squeeze on British privilege. Similar forces are at work today In both eras the hegemons possibly gained privilege during the "pioneer" phase of globalization, but for the British at least, holding on to privilege proved elusive.

As privilege shrinks from, say, $2 \%$ of GDP to $1 \%$ or to zero, this enlarges yet further the adjustment needed to bring a high trade deficit to a long run sustainable level. With the trade deficit around $6 \%$ of GDP, the adjustment grows from $4 \%$ to $5 \%$ to $6 \%$, given near balance on the income account.

\section{Making Adjustment: The Good, The Bad, and the Ugly}

The second part of this paper examines the implications of large adjustments to the external balances, again with an eye to history.

\section{Data and Methodology}

We use a panel data set for over 20 countries between 1880 and 1913 to address the questions posed above. Our data comes from various sources including that used in recent work on crises by Bordo, Eichengreen, Klingebiel and Martínez-Peria (2001) and subsequently updated by Bordo and Meissner (forthcoming). We also make use of the extensive data generated by Obstfeld and Taylor (2003). Our data for current accounts comes from Jones and Obstfeld (2003). Data for the Netherlands come from Smits et al. (2000) and Chile from Braun et al. (2000). Where the Jones and Obstfeld data set did not have information available, we used the trade balance (exports minus imports) following previous studies such as Adalet and Eichengreen (forthcoming) and Catão and Solomou (2005).

We define the core countries to include Belgium, Denmark, Norway, Sweden and Switzerland. These countries were high income countries with robust institutional features but which also imported a fair amount of capital during the period. France, Germany, Great Britain, and the Netherlands, also in the core, are classified as a group of capital exporters and/or financial centers. Since surplus countries often had different experiences in adjustment, we leave these countries out of the core group when we analyze the adjustment process in detail. Furthermore we place Australia, Canada, New 
Zealand and the United States into an "offshoots" category. These regions were extensive capital importers, were settled by immigrants of European origins, and also had a special institutional heritage being members (or once having been members) of the British Empire. The periphery is defined to include Argentina, Austria-Hungary, Brazil, Chile, Egypt, Finland, Greece, India, Italy, Japan, Mexico, Portugal, Russia, Spain, Turkey, Uruguay. We separate the world in this way because the periphery was on average poorer, less financially developed, had institutions that were less conducive to economic growth and relied extensively on external financing due to their low per capita incomes and deficient pools of domestic savings. At the same time, most of the periphery had floating exchange rate regimes for significant portions of the period and only a few spells being on a gold standard. At times we separate countries simply into the rich and poor. We define the rich countries to be those with an income per capita in 1913 higher than $\$ 2,892$ which was the median level of per capita income in 1913 .

\section{Current Account Evolution over Time}

In Figures 13 and 14 we illustrate the distribution of current account surpluses using box and whisker plots. These show the median, the $25^{\text {th }}$ and $75^{\text {th }}$ percentile and the key outliers at either end of the distribution. These also exhibit the adjacent values for each category of country. ${ }^{18}$

Figure 13 shows that the core had persistently higher surpluses although there are quite a few more outliers at each end of the distribution in the core. The offshoots have a skewed distribution. There are many more country years of deficit than of surplus in these regions. There are also fewer outliers than in the other two categories. The periphery seems to be much more bunched towards the middle as the outside values on the bottom end are far fewer in number. Figure 14, which separates countries by whether they are rich, an offshoot, or poor shows a similar picture. Rich countries again have a much more varied experience than either of the two other categories.

Figures 15 through 17 move to a representation of the time series properties of current accounts in each group of countries. Figure 15 shows the unweighted average current account surplus in the core, offshoots and the periphery. Figure 16 divides the world into rich, offshoots and poor. It is clear that there is a strong inverse correlation between movements of the current account in the periphery and in the core. When surpluses in the core countries are high, the periphery tends to move into deficit. These cycles are well known in the historical literature and coincide with movements in the global and especially the British business cycle (cf. Fishlow 1986). In particular when British investment (usually in housing) was high, British capital stayed home and the trade balance in the periphery turned positive. As investment cooled in Britain, capital ventured abroad and allowed for significant increases in the current account deficits of peripheral nations.

Downturns in the global economy (i.e., in Great Britain and the Western European core which made up the principal export markets for the periphery) coincide with increased current account deficits in the periphery as export markets fizzled. ${ }^{19}$

\footnotetext{
${ }^{18}$ These are found by calculating the upper and lower quartiles. Call them p75 and p25. The interquartile range iqr is then $\mathrm{p} 75-\mathrm{p} 25$. The adjacent values are the highest value not greater than $\mathrm{p} 75+3 / 2$ iqr and the lowest value not less than p25 - 3/2 iqr

${ }^{19}$ However, Britain had a persistent trade surplus with India.
} 
Reversals from deficits to surpluses in the periphery are often associated with economic recovery in the core as capital flows emanating from the core dried up. But such reversals in this period tended to be largely healthy in the sense that they were the natural conclusion of a cycle whereby capital flowed into the less developed regions to fund infrastructure and other productive investment. When export markets ripened, exports were able to take off helping to repay obligations previously incurred and smooth the adjustment process.

Figure 17 showing the weighted averages of current account deficits, brings out these co-movements even more clearly. Although weighting in this way should make it so that deficits and surpluses balance out this is not the case here. For most years a downward shift equivalent to 0.5 percent of GDP would make it so that there was global balance. The reason this does not happen in the sample could be because of missing current account information for a small portion of the world's total output. Nevertheless, this figure shows that the total surplus of the core or the total deficit of the periphery was not usually higher than one percent of GDP. This figure does however hide the large and persistent surpluses previously discussed in the case of Britain.

\section{Current Account Persistence}

Early work by Bordo, Eichengreen and Kim (1998) used AR (1) regressions of the current account and compared the past to the present. They found that current account imbalances were significantly more persistent in the past than they have been recently. Taylor (2002) ran separate regressions for 15 countries allowing for dynamic error correction. We generalize this by pooling the data and implementing the following type of vector error correction model

$$
\Delta \frac{C A_{i t}}{G D P_{i t}}=\beta_{i} \frac{C A_{i t-1}}{G D P_{i t-1}}+\gamma_{i} \Delta \frac{C A_{i t-1}}{G D P_{i t-1}} C A_{i t-1}+\mu_{i}+\delta_{t}+\varepsilon_{i t}
$$

Our sample is slightly larger than that in Taylor (2002). Here, the country-specific $\beta_{i}$ s represent the adjustment coefficients for each country in the sample. A small adjustment coefficient (in absolute value) implies that current accounts persist at levels far from their long-run values longer than for countries with larger absolute values. Figure 18 plots these coefficients and reveals an intuitive ranking. The first batch of countries (from right to left) include the financial centers like Britain, France, and Holland. In the next group of countries, we find the extensive capital importers that ran persistent deficits such as Australia, Canada, and the U.S. Their implied half-life for current account deficits is roughly three years. Countries further out on the periphery that tended to indulge in revenue financing on international capital markets or which were smaller and more susceptible to changes in the moods of the capital markets including Chile, Finland, Japan, Uruguay witnessed significantly faster adjustment. Their average coefficient of roughly -0.6 implies a half-life of roughly three-fourths of a year. The bottom line is that many important capital importers were in fact able to run highly persistent deficits and that surplus countries persistently ran current account surpluses.

We also tested whether several country attributes might be associated with the observed persistence of current account deficits. Specifically we allowed the adjustment parameter to vary with the level of exports relative to output, the lagged level of output 
per capita and the level of the government's currency mismatch. Countries with higher levels of exports for a given level of output (used as a proxy for the level of total trade to GDP) could be expected to have an easier time adjusting in the future and hence capital markets might be expected to "keep the money flowing" in the face of global shocks. On average such countries would be expected to run more persistent imbalances.

A similar logic might be used for higher income per capita countries. At the same time, higher income per capita countries also attracted a higher share of British surplus capital because investment opportunities were better there. This division then attempts to control somewhat for differences between imbalances derived from development finance and those associated with stopgap external funding of frivolous government budget deficits. Fishlow (1986) made such a distinction and argued that the latter type of funding could quickly turn around as markets realized borrowing costs were growing more rapidly than revenue streams or the real economy. Fishlow also argued that development finance countries could bide their time in the face of export slow-downs by borrowing even more from the markets as their financial sustainability was not necessarily in doubt. Markets could be expected to fulfill their role here as profitability and revenue would be expected to be higher in the medium term. Similarly, if expectations of faster growth relative to world averages were strongest in the wealthy offshoots, their current account imbalances could be well justified.

We also checked whether countries with a fixed exchange rate or currency mismatch problems on the aggregate balance sheet had any observable differences in persistence. The logic of including a control for whether the country had a gold standard or not is that flexible rates are typically argued to provide shock absorbers and thus equilibrate more quickly any potential imbalances through changes in the real exchange rate much faster. We define the currency mismatch for the economy to be the level of debt outstanding payable in foreign currency or in a fixed amount of gold specie minus the total reserves in the country normalized by the level of exports (cf. Bordo and Meissner forthcoming). Countries with larger mismatches could also face confidence problems, if in the event of a current account reversal, the real exchange rate depreciated making the real burden of repayment more difficult and hence repayment more risky.

To control for all of these risk factors, we ran a regression similar to that above but included interaction terms between the lagged level of the current account and the lagged value of these various controls. If the interaction is found to be positive, it would suggest that the adjustment parameter would move towards zero and hence that such a variable made it easier to sustain current account imbalances. Table 5 shows that countries that have higher per capita output have more persistent imbalances. This is further evidence that the capital exporters and the rich offshoots ran more persistent imbalances. Results regarding the exchange rate regime seem inconclusive. The interaction effect is not highly statistically significant nor is the coefficient on the interaction term very large. This is also the case for the terms that interacted the lagged current account and openness to exports or the currency mismatch variable.

\section{Current Account Reversals}

We now turn to an analysis of the impact of current account reversals on short-run economic growth. Our preferred measure of a reversal is similar to that used in Sebastian 
Edwards (2004). We define a reversal to occur if in a given year the current account relative to GDP increases by more than four percentage points, and in the previous year the country was in deficit.

Table 6 shows the incidence of these "four percent reversals". Financial centers have no reversals in this period. Tabulations show that the core, excluding the financial centers, had twelve reversals accounting for 3.92 percent of the country year observations amongst this group. The periphery had 21 reversals, or 3.86 percent of the country-year observations within this group. So it would appear that outside of the financial centers Britain, Holland, France and Germany there is little difference between the raw frequency of reversals in the core or periphery. In rich countries, excluding the financial centers, the frequency of reversals is double that of the poor countries. In 5.6 percent of the country years there is a reversal in the rich countries while the number is 2.3 percent in poor countries. Together with the previous findings, this suggests that the distribution of reversals in rich countries might have been highly uneven.

Table 7 shows the average levels of the current account relative to GDP in each of the three years before a reversal, the year of the reversal and the three following years. We obtain these coefficients from a regression of the ratio of the current account to GDP on three leads of the reversal indicator, the contemporaneous reversal indicator and three lags. Figure 19 shows how the average values of four different groups evolved over the cycle. The core and offshoots seem somewhat different from the periphery. The core countries run higher deficits than other types of countries. Besides this, there seems to be little significant difference between the various types of breakdowns we use.

We also checked more carefully whether once a reversal had occurred if it was sustained. The answer is for the most part yes. We say a reversal is sustained if three or five years after the reversal the current account surplus is still higher than the year immediately before the reversal. Out of 31 reversals, 27 exhibited a sustained turn around in this way three years after the event. After five years, four of the 29 country-year observations had witnessed a relapse. These statistics reveal that reversals were, if anything, more likely to be sustained in the past than in the last 30 years. Edwards (2004) found that between 68 and 83 percent of reversal episodes were sustained which is slightly lower than our findings.

Another interesting question concerns the relationship between financial crises and current account reversals. Edwards (2004) found that countries experiencing a current account reversal had a significantly greater probability of suffering a large change in the exchange rate (i.e., a currency crisis) than countries that did not have a reversal. The idea that currency crises or sharp changes in the exchange rate could be associated with current account reversals is intuitive. In a reversal, and ceteris paribus, the price at which domestic goods are exchanged for foreign goods must fall with the associated expenditure switching and reduction. If a reversal is associated with a sudden stop of capital inflows and reserves are depleted, then the nominal exchange rate could also fall for the reasons contemporary models of the exchange rate suggest. On the other hand, real depreciation via deflation might be a possibility especially in the gold standard period when many countries had fixed exchange rates under the gold standard. Bordo (2005) discusses how the price-specie flow mechanism operated and suggests that adjustment was often smooth in this period. 
In the rosiest of scenarios originally analyzed by Feis (1930) and later Fishlow (1986), current account reversals are relatively smooth. Early investments give rise to higher incomes which allow for increased savings. They are also a period in which earlier investments made using imported capital begin to pay off. Dividends reaped by the capital exporters from earlier investments are used to fund purchases of goods and services from yesterday's capital importers. These proceeds are used to pay interest and principal on earlier debts incurred and the cycle repeats itself. The historical literature suggests that adjustment may have been more difficult in debtor countries that used external funding for "revenue" purposes than in regions that put funds towards further development of the economy and marketable exportables.

In our data the majority of current account reversals are not associated with currency crises and banking crises. ${ }^{20}$ For the handful of debt crises in our period, there are few reversals surrounding such events. There are no debt crises concurrent with a reversal. Greece had a reversal in the year before its 1894 debt default. Tabulations show that only three of the 33 reversals in our data set are associated with currency crises in the same year. These are Argentina in 1885, Chile in 1898 and Greece in 1885. The banking crises that have concurrent reversals are Australia in 1893, Chile in 1898 and Uruguay in 1913.

There is a possibility that this result is sensitive to the window of observation. So we created a five year window for each type of crisis. This indicator equals one if there was a currency, banking or debt crisis in the current year or within the previous two or next two years. Measured this way, seven out of the 33 reversals are associated with the five year currency crisis window. Ten out of 33 reversals are associated with the five year banking crisis window. As it happens only two of the 33 reversals are associated with our five year window for debt crises.

There does not seem to be overwhelming evidence of an association between crises and reversals in this period. This is particularly so for the richer countries that adhered credibly to the gold standard. Reversals such as those in Australia (1891), Belgium (1881), Denmark (1886), Finland (1893) and New Zealand (1893), to name a few, had no currency crisis associated with them. Most of these countries managed to hold on to their gold-based exchange rates despite suffering reversals and even banking crises. Periphery countries that financed deficits with external borrowing and had mismanaged currencies seem more susceptible to being served up crises along with reversals. This begs the question of what the connection is between the real exchange rate and movements in the current account.

Obstfeld and Rogoff (2004) suggest that today a real effective depreciation of the dollar of over 30 percent would have to arise to allow for enough expenditure switching to rebalance recent U.S. trade deficits. Their model is an endowment economy and does not appear to allow for factors affecting economic growth. This conclusion would seem to bias the result in favor of large exchange rate swings.

The historical literature is not conclusive on the subject. New research by Catão and Solomou (2005) argues that the elasticity of the trade balance (defined as the difference of the log of exports and the log of imports) with respect to the real effective exchange rate was roughly one. Their sample is for a group of 15 countries between 1870

\footnotetext{
${ }^{20}$ We use crisis dates from Bordo, Eichengreen, Klingebiel, and Martínez Peria (2001) that were slightly updated in Bordo and Meissner (forthcoming).
} 
and 1913. We examine this question slightly differently. We present regressions of the change in the logarithm of the real exchange rate (where the nominal exchange rate is local currency units per pound sterling) on the contemporary reversal indicator, three lags of the reversal indicator, and country fixed effects. The regression equation takes the following form:

$$
\Delta R E R_{i t}=\sum_{j=1}^{j=3} \gamma_{k} C A_{-} R E V_{i t+j}+\sum_{k=0}^{k=3} \gamma_{k} C A_{-} R E V_{i t-k}+\mu_{i}+\varepsilon_{i t}
$$

where $C A \_R E V$ equals one when there is a current account reversal. Table 8 shows the short run coefficients for six different specifications. Column 1 pools the data while columns 2, 3, and 4 split the sample by core excluding the financial centers, offshoots and periphery. Columns 5 and 6 compare the experience of country-year observations on the gold standard and those off the gold standard. Figure 20 plots these coefficients. Figure 21 plots the actual sample average and median change in the real exchange from three years before up to three years after a current account reversal. Overall there is some support consistent with the classical price-specie adjustment process. This is most easily seen in the plot of the median real exchange rates. Here we see mild appreciation in the run up to a reversal and mild depreciation after the reversal.

Table 8 and our plots reveal that countries see real appreciation in the years that precede a reversal. The cumulative sum of all post-reversal coefficients is usually positive implying that mild depreciations on the order of two to eight percent are associated with the years following reversals. There is an appreciable difference between gold and non-gold countries. Reversals in the non-gold countries exhibit larger real depreciations after a few years. Deficits are associated with large appreciations that continue into the year of reversal. In gold standard countries, the concomitant depreciation seems much smoother and smaller over the years including and after the reversal. This contrasts with findings by Freund and Warnock (forthcoming) who looked at similar data between 1980 and 2003. They argued that the movement of the real exchange rate did not depend on whether the deficit was large or small. Our findings suggest that the offshoots, which ran the most persistent and highest deficits on average, had significantly smaller depreciations in the reversal period than the periphery and the floating countries.

There are few coefficients on the reversal indicators that are individually statistically significant. However, tests of the hypothesis that the four coefficients are jointly significant show that the current and lagged values are together statistically significantly different from zero in most specifications except the pooled sample and for the gold standard country years. Our conclusion is that the process of adjustment associated with a reversal was associated with mild depreciation in both core and periphery and in gold versus non-gold countries. Many possible explanations for such a pattern exist that contrast with current findings. Stabilizing capital flows, rather than destabilizing speculative flows, and greater price flexibility allowed for smoother adjustment and fewer panics that resemble the first generation variety of currency crises. Finally, rising incomes associated with these large investments also seem to have helped ease the burden of adjustment so that aggregate demand changes were not associated with 
large price swings thus vindicating an Ohlinian view of the conventional transfer problem.

\section{Patterns of Reversals}

In this section we analyze the adjustment process in detail. Mechanically, current account adjustment must be associated with a rise in national savings relative to total investment. The route by which countries get to adjustment can vary quite significantly however. Countries with fiscal deficits could be forced to eliminate such deficits in the face of capital flow reversals. This could lead to sharp falls in output as consumption and investment decline. But not all current account deficits emanated from government deficits and often they reflected high investment in productive enterprises in excess of domestic savings. In such countries a burst of exports based on earlier investments could facilitate adjustment sometimes even offsetting the required reduction in consumption (consumers and government alike). This occurred as incomes expanded and financed the additional savings needed to improve the balance. Nevertheless, Edwards (2004), Adalet and Eichengreeen (forthcoming) and Freund and Warnock (forthcoming) suggest that reversals have been associated with growth slowdowns. These samples are either entirely from the post-1970 period or heavily weighted to describe events post-1913. Given what we have found above, and our reading of the historical literature, there is reason to believe that prior to 1913 the growth impact of reversals might not have been so pernicious.

In what follows we attempt to see whether the various types of countries, which had very different reasons for their current account imbalances, had different adjustment paths. We have data for 15 countries on investment and savings, but the sample is larger when we look at the government surplus and expands appreciably more when we analyze the growth impact of reversals.

Table 9 shows how changes in the ratio of private savings to GDP are associated with changes in the current account. We regress the savings ratios on the contemporaneous and lagged changes in the current account. We also include the lagged level of the dependent variable, the average growth rate of the world's economies, the lagged growth rate of per capita income and country fixed effects. ${ }^{21}$ For comparisons we include standardized beta coefficients for the contemporaneous changes in the current account. These are equal to the estimated coefficient multiplied by the ratio of the standard deviation of the change in the current account in the sample to the standard deviation of the dependent variable.

Unsurprisingly there is a positive relationship between the savings ratio and reversals in all types of countries. However, there is also a difference between the core and the other groups. In the core, the savings ratio is more sensitive to changes in the current account measured by its beta coefficient. In the offshoots and periphery, there is no discernible difference between the impact of changes in the current account on the savings rate.

Table 10 shows the association of the investment to GDP ratio with the current account. The estimating equation follows a parallel specification for the savings equation. Investment declines as the current account strengthens but there are very significant

\footnotetext{
${ }^{21}$ Since $T$ is large (34) for most countries in our panel, the Hurwicz-Nickell bias from including fixed effects and the lagged dependent variable is small, so we eschew GMM and other esoteric methods.
} 
differences between our various groups of countries. In the core and the periphery, investment clearly falls and makes up in the adjustment process what the rise in savings did not. In the offshoots the coefficient on contemporaneous investment is statistically indistinguishable from zero. Nevertheless the sensitivity of investment to changes in the current account in the following year is nearly the same as in the periphery in the contemporaneous year. While the lag structure is slightly different, the coarseness of the data should be taken into account and it is likely that investment moved in a similar way both in the offshoots and the periphery. The conventional wisdom is that savings, possibly out of higher incomes, prevented adjustment from being too choppy in the burgeoning offshoots. The data back this up and suggest that the rise in savings makes up for the majority of the compression in the current account with investment declines accounting for about half as much of the compression.

Changes in public savings make up for the rest of the adjustment as Table 11 demonstrates. Here the dependent variable is the ratio of government surplus to GDP. The point estimates suggest significant differences between our three groups of countries. In the periphery, where borrowing was frequently undertaken to plug fiscal gaps, we see that reversals would tend to be associated with a rise in the government surplus. In the core, and in the offshoots, the point estimates on the contemporaneous current account terms are both negative and statistically indistinguishable from zero.

Together these tables point out that in the past a large majority of the adjustment process came through increased savings. At this stage we are unable to say whether these increases came out of higher incomes generated by previous investments in plant and infrastructure or whether they add up to a decline in aggregate demand. Based on the historical literature, we suspect that in the periphery it is more likely that we would see declines in aggregate output in the wake of current account reversals. This is so because much of the borrowing was not spent on productive enterprises. Even when it was productive, it was invested in development of single commodities that were vulnerable to large price shocks like guano or coffee. The fact that government deficit financing played a larger role in the periphery would tend to damage output growth too. First because much of the expenditure was to pay for current outlays rather than on investments and secondly because this type of borrowing is susceptible to crises of confidence which precipitate relatively large exchange rate swings (as we have seen for the floating periphery in Figure 20) which add up to balance sheet crises as described in Bordo and Meissner (forthcoming).

Tables 13 and 14 show the impact on per capita output growth of current account reversals. Adalet and Eichengreen (forthcoming) argued that reversals have been associated with lower growth in per capita income and Edwards found a similar result for the post-1970 period. Comparing our results directly to Adalet and Eichengreen is difficult because they pool the data between 1880 and 1997. They do not report separate coefficients for each period and follow a slightly different specification by using the average value of growth in the three years after a reversal as the dependent variable.

In Table 12 we follow the specifications from Tables 10 through 12 and use the growth rate of income per capita as the dependent variable. We also include contemporaneous and lagged changes in the current account, the change in world GDP, lagged domestic growth and country level fixed effects. We find little evidence that changes in the current account are associated with changes in the conditional growth rates 
of per capita output. This is true for the pooled sample as it is in each of the sub samples. This is suggestive that current account reversals were not on average costly in terms of lost output during the first era of globalization.

The virtuous cycle of investments, growing local capacity and import absorption in the surplus countries seems to be a stylized fact backed up by a broad statistical analysis of all available data. Moreover, as we have seen, only about a third of the reversals were associated with financial crises. As it happens, even these events do not seem to have been important enough in the overall sample to conclude that reversals are associated with output losses.

In Table 13 we check the robustness of these results by using indicators for our four percent reversals rather than the changes in the current account as the key regressors. Here again we find no overwhelming evidence of slower growth during reversal episodes. In the pooled sample, none of the coefficients on reversals are individually statistically different from zero and jointly they are also statistically insignificant.

Looking at the point estimates we find the following. In the core, growth is above average in the year of a reversal. In the offshoots, growth is lower by about two percentage points two years after a reversal but there is no difference in growth rates in the year of and one year after a reversal. In the periphery, growth appears to be lower one year after a reversal. Again the coefficient is only statistically significant at a generous 90 percent level of confidence. The results here again contrast with those of Freund and Warnock (forthcoming). In the last 30 years they found that larger exchange rate movements led to lower output losses. Since we know the core and the offshoots clung to the gold standard while the periphery typically floated, it appears that, if anything, on average the gold standard countries with rigid exchange rates had higher growth than the periphery. ${ }^{22}$ Taking the cumulative sum of the point estimates suggests that the offshoots themselves do have a larger dip in output in the wake of reversals than the rest of the periphery. This result is almost surely driven by the severe economic crisis in Australia in the 1890s that was analyzed most recently in Adalet and Eichengreen (forthcoming).

In columns 6 through 8 we test whether openness to trade, the level of GDP per capita and currency mismatches affected output losses in the face of a current account reversal. We do so by separately interacting each of these controls with the contemporaneous reversal indicator. Edwards (2004) argued that more open economies were less likely to suffer growth slowdowns after a reversal. In theory a larger currency mismatch could make it so that a larger primary surplus would be needed to maintain fiscal sustainability in the face of a depreciation. An interaction between per capita output and the reversal indicator is ad hoc but asks the data whether stronger institutions and a better financial development allowed for easier adjustment. In column 6 we find that the interaction term with export openness is positive, but the marginal effect of a reversal at any level of openness is not highly statistically significant. Columns 7 and 8 are equally inconclusive. The impact of reversals does not appear to depend on the level of real output per capita nor on the level of the currency mismatch.

Our last two tables suggest that current account reversals were not unambiguously associated with growth disasters in the first golden age of financial globalization. On the whole, the weight of evidence is for a "benign" view of current account reversals. If

\footnotetext{
22 This assertion holds up to more formal testing. When we interact the reversal indicator with the change in the real exchange rate, the marginal effect is not statistically different from zero.
} 
savings was rising and moving more than investment fell during reversals then this would suggest that a vast majority of reversals were accompanied by enough expenditure shifting (i.e., increases in net exports) so as to allow for continued trend growth. This evidence therefore suggests that prior to 1913 current account reversals were just part of a series of mostly amicable games of marbles à la Rueff.

\section{Summary: Smooth or Choppy Adjustment?}

Our overall assessment about current account reversals arises form a period that witnessed profound international integration in trade and capital markets. This integration had the industrial powerhouse of Western Europe behind it promoting capital imports in the periphery to further enhance domestic economic growth. The lending cycles often discussed in the literature are prevalent and emblematic of this largely symbiotic relationship. Reversals did occur and roughly one third of them were accompanied by large swings in exchange rates in the years preceding them or following them. However, capital markets were much more stabilizing in the past. They reacted to local events rather than global events and hence were less contagious (cf. Mauro, Sussman and Yafeh, 2006). That being the case, current accounts persisted especially where markets had the confidence that due care was being taken to ensure profitable investment would eventually come on line.

When reversals came, they were mostly accompanied by mild exchange rate fluctuations on the order of two to eight percent over the adjustment phase-nowhere near the 30 percent effective fluctuations that are envisaged by contemporary accounts of adjustment in the U.S. Growth in exports and higher productive capacity overcame the compression in government expenditure and investment that accompanied reversals and created reversal episodes that were not the growth mishaps that seem to be occurring more frequently these days. Why are the effects so different from era to era? Current account deficits and financial globalization in developing countries these days has often been associated with fiscal excess and failed development attempts. This most resembles what happened in the nineteenth century in the peripheral regions. But recently greater contagion and capital market spillovers have also contributed to international capital markets that seize up and lose liquidity even for good risks. Because of the maturity mismatch problem that afflicts countries, many projects go under funded during the downswing of the cycle. Looking forward after having looked backward, we believe the key determinant of whether current account reversals will be smooth or not will depend on continued confidence in the capital markets and continued efforts to improve future productive capacity in debtor nations. In this case, reversal will more likely be smooth and gentle rather than abrupt and abrasive.

\section{Conclusions}

In this paper we have used a comparative economic history approach to study two hotly debated aspects of the current global imbalances: privilege and adjustment.

We find that the special and privileged position of the United States in the global economy of the late twentieth century appears to be on the wane. We make comparisons with the last imperial and hegemonic power, Britain in the late nineteenth century, and 
find some parallels. Although Britain was a net creditor, its ability to extract privilege appears to have been a phenomenon largely resulting from its status as a global financial pioneer in the 1860s and 1870s. After that period, yield differentials between home and foreign assets closed, and total returns differentials between home and foreign assets fluctuated above and below zero from decade to decade.

For the United States today, as compared to the 1960s, yield privilege appears to be draining away, falling from almost $3 \%$ to less than $1 \%$, despite the rise of riskier foreign investment portfolios. The only reason that privilege has grown as a fraction of GDP is that the leverage has massively increased, with the U.S., like many other countries, vastly expanding its external balance sheet though large gross flows since the 1980s. Naive trend extrapolation is always unwise, but it is especially unwise for privilege as a fraction of GDP, because the underlying trends are countervailing, and cannot be expected to carry on forever in the same way. The only offsetting factor is that U.S. capital gains on external wealth appear to be very strong in recent years, but the origin of these is a mystery and their extrapolation even more subject to doubt. If privilege continues to disappear as it has in the past then, all else equal, an even larger adjustment will be needed.

What can history teach us about adjustment? We have examined the experience of a large sample of countries and compared their adjustment experiences with those from the recent past. There are striking differences between the results from the recent period and those from the past. Most notably current account deficits were often highly persistent while the adjustment process was not always as fraught with the economic distress economists typically predict today.

Part of this suggests that persistent current account deficits backed by sound investments will pay dividends and expenditure switching and reduction will not have to be as abrupt as is commonly implied. The large and liquid capital market of London channeled local funds to emerging markets via fixed income investments and it managed to discriminate between good and bad borrowers. This led to differences in the willingness with which future deficits could be funded. It followed that the deficits in the fast-growing but capital poor countries were sustainable and they had rather smooth adjustments. This is to say that if history is any guide, the extent to which a hard landing will follow today's current imbalances could hinge importantly on the confidence of the capital markets which is ultimately likely to be driven by the fundamentals. 


\section{References}

Adalet, Muge and Barry Eichengreen. Forthcoming. Current Account Reversals: Always a Problem? In G7 Current Account Imbalances: Sustainability and Adjustment edited by Richard Clarida. Chicago: University of Chicago Press.

Bordo, Michael D. 2005. Historical Perspectives on Global Imbalances. NBER working paper 11383.

Bordo, Michael D., Barry Eichengreen, and Jong Woo Kim. 1998. Was There Really an Earlier Period of International Financial Integration Compared to Today? In The Implications of Globalization of World Financial Markets edited by the Bank of Korea. Seoul: Bank of Korea.

Bordo, Michael D., Barry Eichengreen, Daniela Klingebiel, Maria Soledad MartínezPeria. 2001. Is the Crisis Problem Growing More Severe? Economic Policy 32, 51-75.

Bordo, Michael D., and Christopher M. Meissner. Forthcoming. Financial Crises, 18801913: The Role of Foreign Currency Debt. In Growth, Institutions and Crises: Latin America from a Historical Perspective edited by Sebastian Edwards. Chicago: University of Chicago Press.

Braun, Juan, Matías Braun, Ignacio Briones, José Díaz, Rolf Lüders, and Gert Wagner. 2000. Economia Chilena 1810-1995: Estadisticas Historicas Santiago:Pontificia Universidad Catolica de Chile Instituto de Economia.

Buiter, Willem. 2006. Dark Matter or Cold Fusion? Global Economics Paper no. 136, London: Goldman Sachs (16 January).

Catão, Luis A.V. and Solomou, Solomos N. 2005. Effective Exchange Rates and the Classical Gold Standard Adjustment. American Economic Review 95(4), pp. 1259-1275.

Cline, William, R. 2005. The United States as a Debtor Nation. Washington, DC: Institute for International Economics.

Davis, Lance E., and Robert A. Huttenback, with Susan Gray Davis. 1986. Mammon and the Pursuit of Empire: The Political Economy of British Imperialism, 1860-1912. Cambridge: Cambridge University Press.

Despres, Emile, Charles Kindlerger, and Walter Salant. 1966. The Dollar and World Liquidity: A Minority View. The Economist, February 5, pp. 526-29

Edelstein, Michael. 1982. Overseas Investment in the Age of High Imperialism. New York: Columbia University Press.

Edwards, Sebastian. 2004. Thirty Years of Current Account Imbalances, Current Account Reversals, and Sudden Stops" IMF Staff Papers (51) pp. 1-49.

Eichengreen, Barry. 2006. Global Imbalances: The New Economy, the Dark Matter, the Savvy Investor, and the Standard Analysis. Journal of Policy Modeling. Forthcoming.

Feis, Herbert. 1930. Europe: The World's Banker, New Haven: Yale University Press.

Fishlow, Albert. 1986. Lessons from the Past, Capital Markets and International Lending in the $19^{\text {th }}$ Century and the Interwar Years. In The Politics of International Debt edited by Miles Kahler. Ithaca, N.Y.: Cornell University Press. 
Foreman-Peck, James. 1995. A History of the World Economy: International Economic Relations Since 1850, 2nd ed. New York, N.Y.: Harvester Wheatsheaf.

Freund, Caroline and Frank Warnock. Forthcoming. Current Account Deficits in Industrial Countries: The Bigger They Are, The Harder They Fall? In G7 Current Account Imbalances: Sustainability and Adjustment edited by Richard Clarida. Chicago: University of Chicago Press.

Geithner, Timothy F. 2006. Policy Implications of Global Imbalances. Remarks at the Global Financial Imbalances Conference at Chatham House, London, January 23, 2006. Federal Reserve Bank of New York.

Gourinchas, Pierre-Olivier, and Hélène Rey. Forthcoming. From World Banker to World Venture Capitalist: U.S. External Adjustment and the Exorbitant Privilege. In G7 Current Account Imbalances: Sustainability and Adjustment edited by Richard Clarida. Chicago: University of Chicago Press.

Gros, Daniel. 2006. Foreign Investment in the U.S. (II): Being taken to the cleaners? Centre for European Policy Studies. CEPS Working Document, no. 243/April 2006.

Hausmann, Ricardo and Federico Sturzenegger. 2006. Global imbalances or bad accounting? The missing dark matter in the wealth of nations. Working Paper, Kennedy School of Government, May.

Higgins, Matthew, Thomas Klitgaard, and Cedric Tille. 2005 The Income Implications of Rising U.S. International Liabilities. Current Issues in Economics and Finance, Federal Reserve Bank of New York, December.

Imlah, Albert H. 1958. Economic Elements of the Pax Brittanica. Cambridge, Massachusetts: Harvard University Press.

Jones, Matthew T. and Maurice Obstfeld Saving, Investment, and Gold: A Reassessment of Historical Current Account Data available at http://www.nber.org/databases/jonesobstfeld/

Kitchen, John. 2006. Sharecroppers or Shrewd Capitalists? Projections of the U.S. Current Account, International Income Flows, and Net International Debt. Unpublished manuscript, Office of Management and Budget (February).

Kugler, Peter and Beatrice Weder, 2005. Why Are Returns on Swiss Franc Assets So Low? Rare Events May Solve the Puzzle. CEPR Discussion Papers 5181.

Lane, Philip R., and Gian Maria Milesi-Ferretti. 2003. International Financial Integration. IMF Staff Papers 50 (September), pp. 82-113.

Lane, Philip R., and Gian Maria Milesi-Ferretti. 2004. The Transfer Problem Revisited: Net Foreign Assets and Real Exchange Rates. Review of Economics and Statistics 86(4): 841-57.

Lane, Philip R., and Gian Maria Milesi-Ferretti. 2005a. Financial Globalization and Exchange Rates. IMF Working Papers 05/3, International Monetary Fund.

Lane, Philip R., and Gian Maria Milesi-Ferretti. 2005b. A Global Perspective on External Positions. IMF Working Papers 05/161, International Monetary Fund.

Mauro, Paolo, Nathan Sussman and Yishay Yafeh. 2006. Emerging Markets and Financial Globalization: Sovereign Bond Spreads in 1870-1913 and Today. Oxford: Oxford University Press.

Nickell, Stephen. 2006. The U.K. Current Account Deficit and All That. Unpublished paper. Bank of England, 25 April. 
Obstfeld, Maurice, and Rogoff, Kenneth. 2004. The Unsustainable U.S. Current Account Position Revisited. NBER working paper 10869.

Obstfeld, Maurice, and Alan M. Taylor. 2003. Sovereign Risk, Credibility and the Gold Standard, 1870-1913 versus 1925-1931. Economic Journal, 113 (487), pp. 1-35.

Obstfeld, Maurice, and Alan M. Taylor. 2004. Global Capital Markets: Integration, Crisis, and Growth. Cambridge: Cambridge University Press.

Roubini, Nouriel, and Brad Setser. 2004. The U.S. as a Net Debtor: The Sustainability of the U.S. External Imbalances. Unpublished manuscript, Stern School of Business, New York University.

Smits, Jan-Pieter, Edwin Horlings, Jan Luiten van Zanden. 2000. Dutch GNP and its Components, 1800-1913. GGDC Research Memorandum No. 5, Groningen Growth and Development Centre, University of Groningen.

Taylor, Alan M. 2002. A Century of Current Account Dynamics. Journal of International Money and Finance 21 pp. 725-748. 
Table 1

Privilege: Relative to GDP

(a) Estimates

Dependent Variable is NFIA/GDP

\begin{tabular}{|c|c|c|c|c|c|c|}
\hline & \multicolumn{2}{|c|}{$\begin{array}{l}\text { U.S. } \\
1981-2003\end{array}$} & \multicolumn{2}{|l|}{$\begin{array}{l}\text { G7 } \\
1981-2003\end{array}$} & \multicolumn{2}{|l|}{$\begin{array}{l}\text { U.K. } \\
1870-1913\end{array}$} \\
\hline & (1) & (2) & (3) & $(4)$ & (5) & $(6)$ \\
\hline \multirow[t]{2}{*}{ NFA/GDP } & 0.023 & 0.001 & 0.025 & 0.015 & 0.040 & 0.039 \\
\hline & $(4.16) * *$ & $(0.08)$ & $(4.39) * *$ & $(1.98) *$ & $(16.51) * *$ & $(16.16) * *$ \\
\hline \multirow[t]{2}{*}{ INFL*NFA/GDP } & & 0.915 & & 0.332 & & 0.019 \\
\hline & & $(1.76)$ & & $(2.12) *$ & & $(0.90)$ \\
\hline \multirow{2}{*}{ U.S.A } & 0.005 & 0.005 & 0.005 & 0.005 & & \\
\hline & $(9.95) * *$ & $(10.46) * *$ & $(4.96) * *$ & $(4.87) * *$ & & \\
\hline \multirow[t]{2}{*}{ GBR } & & & 0.006 & 0.005 & 0.006 & 0.007 \\
\hline & & & $(5.38) * \star$ & $(5.22) \star \star$ & $(1.89)$ & $(1.99)$ \\
\hline \multirow[t]{2}{*}{ CAN } & & & -0.026 & -0.025 & & \\
\hline & & & $(11.78) * *$ & $(11.53) * *$ & & \\
\hline \multirow[t]{2}{*}{ FRA } & & & 0.002 & 0.002 & & \\
\hline & & & $(1.49)$ & $(1.56)$ & & \\
\hline \multirow[t]{2}{*}{$\overline{\mathrm{DEU}}$} & & & 0.002 & 0.002 & & \\
\hline & & & $(1.82)$ & $(1.77)$ & & \\
\hline \multirow[t]{2}{*}{ ITA } & & & -0.008 & -0.008 & & \\
\hline & & & $(7.09) \star \star$ & $(7.04) \star \star$ & & \\
\hline \multirow[t]{2}{*}{ JPN } & & & 0.006 & 0.006 & & \\
\hline & & & $(5.32) \star \star$ & $(5.50) \star \star$ & & \\
\hline Observations & 23 & 23 & 161 & 161 & 44 & 44 \\
\hline R-squared & 0.45 & 0.52 & 0.89 & 0.90 & 0.87 & 0.87 \\
\hline
\end{tabular}

(b) Frequency of "Privilege" / Penalty" $\dagger$

\begin{tabular}{|l|l|l|l|l|l|l|}
\hline U.S.A & $100 \% / 0 \%$ & $100 \% / 0 \%$ & $100 \% / 0 \%$ & $100 \% / 0 \%$ & & \\
\hline GBR & & & $76 \% / 9 \%$ & $71 \% / 9 \%$ & $80 \% / 0 \%$ & $85 \% / 0 \%$ \\
\hline CAN & & & $32 \% / 68 \%$ & $32 \% / 68 \%$ & & \\
\hline FRA & & & $56 \% / 24 \%$ & $56 \% / 18 \%$ & & \\
\hline DEU & & & $66 \% / 16 \%$ & $66 \% / 16 \%$ & & \\
\hline ITA & & & $32 \% / 68 \%$ & $32 \% / 65 \%$ & & \\
\hline JPN & & & $94 \% / 0 \%$ & $94 \% / 0 \%$ & & \\
\hline
\end{tabular}

Absolute value of $t$ statistics in parentheses

* Significant at 5\%

** Significant at $1 \%$

$\dagger$ Observations more than $2 \mathrm{s.d}$. above/below $r$ NFA/GDP, where $r$ is the slope estimate. 
Table 2

Privilege: Relative to GDP, "Early" v "Late"

Dependent Variable is NFIA/GDP

\begin{tabular}{|l|l|l|}
\hline & $\mathrm{U} . \mathrm{S}$. & $\mathrm{U} . \mathrm{K}$. \\
& $1981-2003$ & $1870-1913$ \\
\hline & $(1)$ & $(2)$ \\
\hline NFA/GDP & 0.013 & 0.051 \\
\hline EARLY & $(1.75)$ & $(11.41) * *$ \\
\hline & 0.002 & 0.009 \\
\hline U.S.A & $(1.69)$ & $(2.93) * *$ \\
\hline GBR & 0.004 & \\
\hline & $(3.45) * *$ & -0.011 \\
\hline Observations & & $(1.69)$ \\
\hline R-squared & & 44 \\
\hline
\end{tabular}

Absolute value of $t$ statistics in parentheses

* Significant at $5 \%$

* * Significant at $1 \%$

EARLY $=1$ when year is less than or equal to 1880 (U.K.) or 1992 (U.S.). 
Table 3

G7 Rate of Yield Differentials (Assets versus Liabilities), 1981-2003

\begin{tabular}{lrcrrr} 
& Obs & Mean & Std.Error & \multicolumn{2}{c}{ [95\% confidence interval] } \\
U.S.A & 23 & $0.0167 *$ & 0.0018 & 0.0130 & 0.0204 \\
GBR & 23 & 0.0009 & 0.0010 & -0.0011 & 0.0030 \\
CAN & 23 & $-0.0139 *$ & 0.0021 & -0.0182 & -0.0096 \\
FRA & 23 & $0.0080 *$ & 0.0015 & 0.0049 & 0.0111 \\
DEU & 23 & 0.0032 & 0.0016 & -0.0002 & 0.0066 \\
ITA & 23 & $-0.0052 *$ & 0.0015 & -0.0083 & -0.0021 \\
JPN & 23 & $0.0112 *$ & 0.0013 & 0.0084 & 0.0140
\end{tabular}

* significant at the 5\% level

Table 4

G7 Total Rate of Return Differentials (Assets versus Liabilities), 19812003

$\begin{array}{lrrrcr} & \text { Obs } & \text { Mean } & \text { Std.Error. } & \text { [95\% confidence interval] } \\ \text { U.S.A } & 23 & 0.0369 * & 0.0117 & 0.0127 & 0.0612 \\ \text { GBR } & 23 & 0.0025 & 0.0060 & -0.0099 & 0.0149 \\ \text { CAN } & 23 & -0.0006 & 0.0151 & -0.0319 & 0.0307 \\ \text { FRA } & 23 & 0.0019 & 0.0091 & -0.0170 & 0.0207 \\ \text { DEU } & 23 & -0.0062 & 0.0058 & -0.0183 & 0.0059 \\ \text { ITA } & 23 & -0.0034 & 0.0087 & -0.0215 & 0.0147 \\ \text { JPN } & 17 & 0.0009 & 0.0186 & -0.0385 & 0.0403\end{array}$

* significant at the 5\% level 
Table 5

Current Account Adjustment and its Determinants

\begin{tabular}{l|c}
\hline Regressors & $(1)$ \\
\hline Current Account $t-1$ & -2.26 \\
& {$[0.72]^{\star *}$} \\
Change in the Current Account $t-1$ & -0.12 \\
Current Account x Gold Standard $t-1$ & {$[0.09]$} \\
Current Account x In(Real GDP per cap.) $t-1$ & -0.20 \\
Current Account x Exports/GDP $t-1$ & {$[0.10]$} \\
Current Account x Currency Mismatch $t-1$ & 0.27 \\
Gold Standard & {$[0.09]^{\star *}$} \\
In (Real GDP per cap.) & 0.00 \\
Exports/GDP & {$[0.00]$} \\
Currency Mismatch & 0.04 \\
Change in log of the real exchange rate & {$[0.04]$} \\
Constant & -0.91 \\
& {$[0.41]^{\star}$} \\
\hline \hline Nomber of obs & -1.23 \\
& {$[1.89]$} \\
& -0.12 \\
& {$[0.03]^{\star *}$}
\end{tabular}

Notes: Dependent variable is change in the ratio of the current account to GDP. The regression includes country fixed effects and year dummies. Robust clustered standard errors are in parentheses. See the text for precise definitions of variables.

$*$ p-value $<0.1 ; * *$ p-value $<0.05 ; * * *$ p-value $<0.01$ 
Table 6

Countries and Years of Current Account Reversals

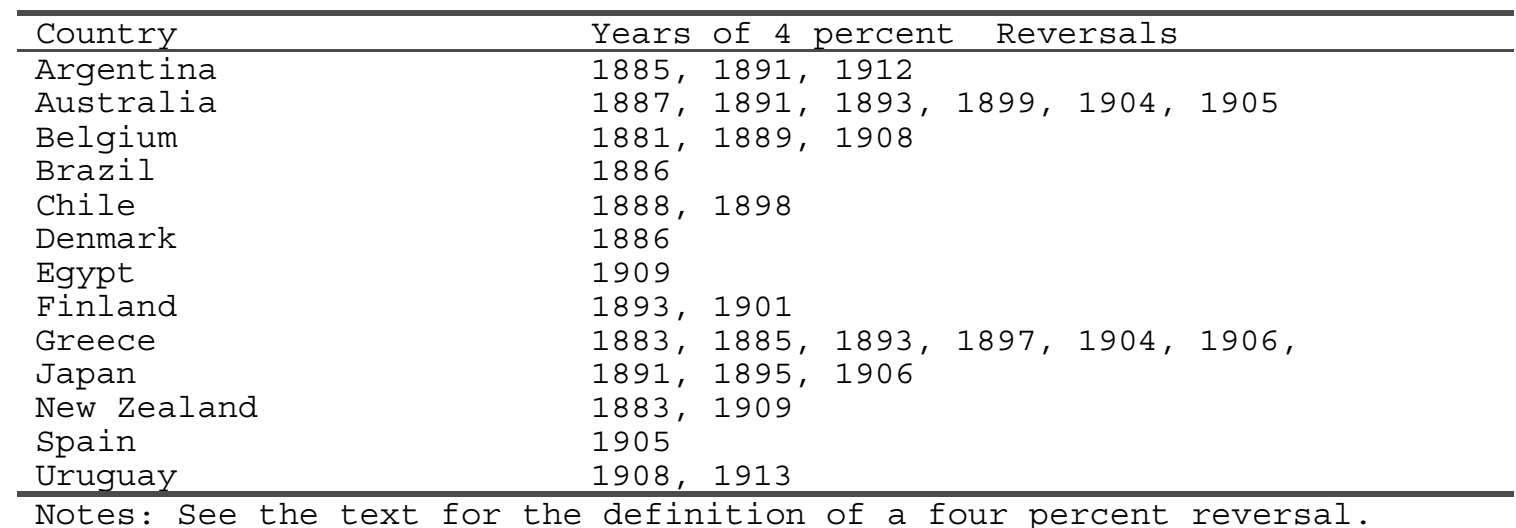


Table 7

Average Current Account Levels Before and After a Reversal

\begin{tabular}{|c|c|c|c|c|c|c|}
\hline Regressors & $\begin{array}{c}\text { Pooled } \\
\text { (1) }\end{array}$ & $\begin{array}{c}\text { Core ex. Financial Ctrs } \\
\text { ex. Offshoots } \\
\text { (2) }\end{array}$ & $\begin{array}{l}\text { Offshoots } \\
\text { (3) }\end{array}$ & $\begin{array}{l}\text { Periphery } \\
\text { (4) }\end{array}$ & $\begin{array}{c}\text { Gold Std. Ctry-Years } \\
\text { (5) }\end{array}$ & $\begin{array}{c}\text { Non-Gold Ctry-Yrs } \\
\text { (6) }\end{array}$ \\
\hline \multirow{2}{*}{ Current Account Reversal $t+3$} & -4.79 & -8.10 & -6.27 & -4.24 & -4.27 & -5.83 \\
\hline & {$[1.33]^{\star \star}$} & {$[3.45]^{\star}$} & {$[2.57]^{\star}$} & {$[1.75]^{\star}$} & {$[1.32]^{* \star}$} & {$[2.85]^{*}$} \\
\hline \multirow[t]{2}{*}{ Current Account Reversal $t+2$} & -5.75 & -7.48 & -6.91 & -5.21 & -5.38 & -6.30 \\
\hline & {$[1.34]^{\star \star}$} & {$[2.65]^{\star \star}$} & {$[2.46]^{\star \star}$} & {$[1.82]^{\star \star}$} & {$[1.28]^{\star \star}$} & {$[2.85]^{*}$} \\
\hline \multirow[t]{2}{*}{ Current Account Reversal $t+1$} & -7.88 & -12.77 & -7.58 & -7.19 & -8.17 & -7.21 \\
\hline & {$[1.19]^{\star \star}$} & {$[6.11]^{*}$} & {$[1.84]^{\star \star}$} & {$[1.28]^{\star \star}$} & {$[1.46]^{\star \star}$} & {$[1.93]^{\star \star}$} \\
\hline \multirow{2}{*}{ Current Account Reversal } & -1.39 & -3.24 & -1.28 & -1.31 & -1.13 & -1.83 \\
\hline & {$[1.05]$} & [2.57] & [1.81] & {$[1.44]$} & {$[0.96]$} & [2.38] \\
\hline \multirow{2}{*}{ Current Account Reversal $t-1$} & -2.55 & -7.52 & -1.33 & -2.50 & -1.45 & -3.81 \\
\hline & {$[1.33]$} & [4.02] & [2.12] & [1.73] & {$[1.65]$} & [2.15] \\
\hline \multirow[t]{2}{*}{ Current Account Reversal $t-2$} & -3.72 & -7.52 & -1.80 & -3.80 & -3.65 & -4.00 \\
\hline & {$[1.08]^{\star \star}$} & {$[2.16]^{\star *}$} & [1.57] & {$[1.41]^{\star \star}$} & {$[1.07]^{\star \star}$} & [2.08] \\
\hline \multirow[t]{2}{*}{ Current Account Reversal $t-3$} & -2.40 & -3.43 & 0.45 & -3.38 & -1.56 & -3.34 \\
\hline & {$[1.14]^{\star}$} & {$[0.24]^{\star \star}$} & [1.49] & {$[1.63]^{\star}$} & {$[0.83]$} & [2.13] \\
\hline Number of obs & 728 & 138 & 112 & 366 & 521 & 207 \\
\hline R-squared & 0.17 & 0.17 & 0.30 & 0.20 & 0.13 & 0.32 \\
\hline
\end{tabular}
Notes: Dependent variable is the level of the current account. All regressions include country fixed effects. Robust clustered standard errors are in parentheses. See the text for precise

$* \mathrm{p}$-value $<0.1 ; * * \mathrm{p}$-value $<0.05 ; * * * \mathrm{p}$-value $<0.01$

Table 8

Changes in Real Exchange Rates Before and After Current Account Reversals

\begin{tabular}{|c|c|c|c|c|c|c|}
\hline Regressors & $\begin{array}{l}\text { Pooled } \\
\text { (1) }\end{array}$ & $\begin{array}{l}\text { Core ex. Financial Ctrs } \\
\text { ex. Offshoots } \\
\text { (2) }\end{array}$ & $\begin{array}{l}\text { Offshoots } \\
\text { (3) }\end{array}$ & $\begin{array}{l}\text { Periphery } \\
\text { (4) }\end{array}$ & $\begin{array}{c}\text { Gold Std. Ctry-Years } \\
\text { (5) }\end{array}$ & $\begin{array}{c}\text { Non-Gold Ctry-Yrs } \\
\text { (6) }\end{array}$ \\
\hline \multirow{2}{*}{ Current Account Reversal $t+3$} & -0.01 & 0.03 & -0.01 & -0.02 & -0.02 & 0.01 \\
\hline & {$[0.01]$} & [0.02] & {$[0.01]$} & {$[0.02]$} & {$[0.01]$} & {$[0.02]$} \\
\hline \multirow[t]{2}{*}{ Current Account Reversal $t+2$} & 0.01 & -0.05 & -0.01 & 0.03 & -0.02 & 0.08 \\
\hline & {$[0.02]$} & {$[0.01]^{* *}$} & {$[0.01]$} & {$[0.03]$} & {$[0.02]$} & {$[0.04]$} \\
\hline \multirow[t]{2}{*}{ Current Account Reversal $t+1$} & -0.02 & -0.01 & 0.01 & -0.04 & 0 & -0.07 \\
\hline & {$[0.01]$} & {$[0.01]$} & [0.02] & {$[0.02]^{*}$} & {$[0.01]$} & {$[0.04]$} \\
\hline \multirow[t]{2}{*}{ Current Account Reversal } & -0.02 & -0.01 & 0 & -0.04 & 0.01 & -0.09 \\
\hline & {$[0.01]$} & {$[0.01]$} & {$[0.01]$} & {$[0.02]$} & {$[0.01]$} & {$[0.03]^{* *}$} \\
\hline \multirow[t]{2}{*}{ Current Account Reversal $t-1$} & 0 & -0.01 & 0.02 & -0.01 & 0.01 & -0.01 \\
\hline & {$[0.01]$} & [0.02] & {$[0.01]^{*}$} & [0.02] & {$[0.01]$} & {$[0.03]$} \\
\hline \multirow{2}{*}{ Current Account Reversal $t-2$} & 0 & 0.01 & -0.01 & 0 & 0 & 0 \\
\hline & {$[0.02]$} & {$[0.01]$} & {$[0.02]$} & {$[0.03]$} & {$[0.01]$} & {$[0.04]$} \\
\hline \multirow[t]{2}{*}{ Current Account Reversal $t-3$} & 0.03 & 0.02 & -0.01 & 0.05 & 0 & 0.07 \\
\hline & {$[0.01]^{*}$} & {$[0.02]$} & {$[0.01]$} & {$[0.02]^{*}$} & {$[0.01]$} & {$[0.02]^{\star *}$} \\
\hline Number of obs & 689 & 140 & 112 & 353 & 495 & 194 \\
\hline F-Statistic & 1.11 & $3.60^{* \star *}$ & $1.77^{\star}$ & $1.77^{\star}$ & 0.83 & $3.03^{* * *}$ \\
\hline R-squared & 0.02 & 0.09 & 0.06 & 0.04 & 0.01 & 0.11 \\
\hline
\end{tabular}

Notes: Dependent variable is the change in the real exchange rate. Robust clustered standard errors are in parentheses. See the text for precise definitions of variables.

* $\mathrm{p}$-value $<0.1 ; * * \mathrm{p}$-value $<0.05 ; * * * \mathrm{p}$-value $<0.01$ 
Table 9

Dynamics of the Ratio of Savings to GDP

\begin{tabular}{|c|c|c|c|c|}
\hline Regressors & $\begin{array}{c}\text { Pooled } \\
\text { (1) }\end{array}$ & $\begin{array}{c}\text { Core ex. Financial Ctrs } \\
\text { ex. Offshoots } \\
\text { (2) }\end{array}$ & $\begin{array}{c}\text { Offshoots } \\
\text { (3) }\end{array}$ & $\begin{array}{c}\text { Periphery } \\
\text { (4) }\end{array}$ \\
\hline $\mathrm{S} / \mathrm{GDP} t-1$ & $\begin{array}{c}-0.23 \\
{[0.05]^{\star *}}\end{array}$ & $\begin{array}{l}-0.02 \\
{[0.02]}\end{array}$ & $\begin{array}{l}-0.17 \\
{[0.06]}\end{array}$ & $\begin{array}{c}-0.21 \\
{[0.03]^{\star *}}\end{array}$ \\
\hline Change in Ratio of Current Account to GDP & $\begin{array}{c}0.78 / 0.49 \\
{[0.09]^{\star *}}\end{array}$ & $\begin{array}{c}0.71 / 0.73 \\
{[0.01]^{\star *}}\end{array}$ & $\begin{array}{c}0.85 / 0.56 \\
{[0.17]^{*}}\end{array}$ & $\begin{array}{c}0.83 / 0.54 \\
{[0.22]^{*}}\end{array}$ \\
\hline Lagged Change in Ratio of Current Account to GDP & $\begin{array}{l}-0.13 \\
{[0.07]}\end{array}$ & $\begin{array}{c}0.04 \\
{[0.06]}\end{array}$ & $\begin{array}{l}-0.15 \\
{[0.06]}\end{array}$ & $\begin{array}{l}-0.04 \\
{[0.09]}\end{array}$ \\
\hline Avg. Growth Rate of GDP All Countries & $\begin{array}{l}-0.01 \\
{[0.09]}\end{array}$ & $\begin{array}{c}0.09 \\
{[0.01]^{*}}\end{array}$ & $\begin{array}{c}0.07 \\
{[0.10]}\end{array}$ & $\begin{array}{l}-0.04 \\
{[0.11]}\end{array}$ \\
\hline Lagged Growth in per capita GDP & $\begin{array}{l}-0.03 \\
{[0.04]}\end{array}$ & $\begin{array}{l}-0.03 \\
{[0.03]}\end{array}$ & $\begin{array}{l}-0.02 \\
{[0.10]}\end{array}$ & $\begin{array}{l}-0.06 \\
{[0.05]}\end{array}$ \\
\hline Constant & $\begin{array}{c}3.10 \\
{[0.78]^{\star \star}}\end{array}$ & $\begin{array}{c}0.37 \\
{[0.26]}\end{array}$ & $\begin{array}{c}2.06 \\
{[0.86]} \\
\end{array}$ & $\begin{array}{c}2.27 \\
{[0.24]^{\star \star}}\end{array}$ \\
\hline $\begin{array}{l}\text { Number of obs } \\
\text { R-squared }\end{array}$ & $\begin{array}{l}471 \\
0.41\end{array}$ & $\begin{array}{c}96 \\
0.55\end{array}$ & $\begin{array}{c}96 \\
0.44\end{array}$ & $\begin{array}{l}151 \\
0.45\end{array}$ \\
\hline
\end{tabular}

Notes: Dependent variable is the change in the ratio of domestic savings to GDP. All regressions include country fixed effects. Robust clustered standard errors are in parentheses. See the text for precise definitions of variables.

Absolute values of standardized beta coefficients are listed in row 2 after the estimated coefficients.

${ }^{*} \mathrm{p}$-value $<0.1 ;{ }^{* *} \mathrm{p}$-value $<0.05 ;{ }^{* * *} \mathrm{p}$-value $<0.01$

Table 10

Dynamics of the Ratio of Investment to GDP

\begin{tabular}{|c|c|c|c|c|}
\hline Regressors & $\begin{array}{c}\text { Pooled } \\
\text { (1) }\end{array}$ & $\begin{array}{c}\text { Core ex. Financial Ctrs } \\
\text { ex. Offshoots } \\
\text { (2) }\end{array}$ & $\begin{array}{l}\text { Offshoots } \\
\text { (3) }\end{array}$ & $\begin{array}{c}\text { Periphery } \\
\text { (4) }\end{array}$ \\
\hline I/GDP $t-1$ & $\begin{array}{c}-0.23 \\
{[0.06]^{\star *}}\end{array}$ & $\begin{array}{l}-0.10 \\
{[0.04]}\end{array}$ & $\begin{array}{l}-0.17 \\
{[0.11]}\end{array}$ & $\begin{array}{c}-0.30 \\
{[0.06]^{\star *}}\end{array}$ \\
\hline Change in Ratio of Current Account to GDP & $\begin{array}{c}-0.17 / 0.18 \\
{[0.06]^{*}}\end{array}$ & $\begin{array}{c}-0.27 / 0.38 \\
{[0.00]^{\star *}}\end{array}$ & $\begin{array}{c}-0.07 / 0.06 \\
{[0.17]}\end{array}$ & $\begin{array}{c}-0.24 / 0.26 \\
{[0.08]^{*}}\end{array}$ \\
\hline Lagged Change in Ratio of Current Account to GDP & $\begin{array}{c}-0.18 \\
{[0.04]^{\star \star}}\end{array}$ & $\begin{array}{c}0.01 \\
{[0.06]}\end{array}$ & $\begin{array}{c}-0.25 \\
{[0.05]^{*}}\end{array}$ & $\begin{array}{l}-0.19 \\
{[0.11]}\end{array}$ \\
\hline Avg. Growth Rate of GDP All Countries & $\begin{array}{c}0.08 \\
{[0.05]}\end{array}$ & $\begin{array}{c}0.11 \\
{[0.01]^{* *}}\end{array}$ & $\begin{array}{c}0.05 \\
{[0.14]}\end{array}$ & $\begin{array}{c}0.10 \\
{[0.06]}\end{array}$ \\
\hline Lagged Growth in per capita GDP & $\begin{array}{c}0.01 \\
{[0.05]}\end{array}$ & $\begin{array}{l}-0.01 \\
{[0.03]}\end{array}$ & $\begin{array}{l}-0.03 \\
{[0.09]}\end{array}$ & $\begin{array}{c}0.03 \\
{[0.09]}\end{array}$ \\
\hline Constant & $\begin{array}{c}3.25 \\
{[0.89]^{* *}}\end{array}$ & $\begin{array}{r}1.43 \\
{[0.68]} \\
\end{array}$ & $\begin{array}{r}3.00 \\
{[2.30]}\end{array}$ & $\begin{array}{c}3.65 \\
{[0.83]^{\star}}\end{array}$ \\
\hline $\begin{array}{l}\text { Number of obs } \\
\text { R-squared }\end{array}$ & $\begin{array}{l}471 \\
0.17\end{array}$ & $\begin{array}{c}96 \\
0.23\end{array}$ & $\begin{array}{c}96 \\
0.12\end{array}$ & $\begin{array}{l}151 \\
0.24\end{array}$ \\
\hline
\end{tabular}

Notes: Dependent variable is the change in the ratio of investment to GDP. All regressions include country fixed effects. Robust clustered standard errors are in parentheses. See the text for precise definitions of variables.

Absolute values of standardized beta coefficients are listed in row 2 after the estimated coefficients.

${ }^{*}$ p-value $<0.1 ;{ }^{* *}$ p-value $<0.05 ;{ }^{* * *} p$-value $<0.01$ 
Table 11

Dynamics of the Government Surplus Divided by GDP, 1880-1913

\begin{tabular}{|c|c|c|c|c|}
\hline Regressors & $\begin{array}{l}\text { Pooled } \\
\text { (1) }\end{array}$ & $\begin{array}{c}\text { Core ex. Financial Ctrs } \\
\text { Ex. Offshoots } \\
\text { (2) }\end{array}$ & $\begin{array}{l}\text { Offshoots } \\
\text { (3) }\end{array}$ & $\begin{array}{c}\text { Periphery } \\
\text { (4) }\end{array}$ \\
\hline Govt. Surplus/GDP $t-1$ & $\begin{array}{c}-0.77 \\
{[0.11]^{\star *}}\end{array}$ & $\begin{array}{c}-0.71 \\
{[0.19]^{\star}}\end{array}$ & $\begin{array}{c}-0.31 \\
{[0.08]^{*}}\end{array}$ & $\begin{array}{c}-0.83 \\
{[0.12]^{\star \star}}\end{array}$ \\
\hline Change in Ratio of Current Account to GDP & $\begin{array}{c}0.05 / 0.05 \\
{[0.03]}\end{array}$ & $\begin{array}{c}-0.02 / 0.04 \\
{[0.04]}\end{array}$ & $\begin{array}{c}-0.02 / 0.06 \\
{[0.03]}\end{array}$ & $\begin{array}{c}0.10 / 0.08 \\
{[0.05]^{\star}}\end{array}$ \\
\hline Lagged Change in Ratio of Current Account to GDP & $\begin{array}{l}-0.02 \\
{[0.07]}\end{array}$ & $\begin{array}{l}-0.08 \\
{[0.04]}\end{array}$ & $\begin{array}{c}0.06 \\
{[0.03]}\end{array}$ & $\begin{array}{l}-0.04 \\
{[0.11]}\end{array}$ \\
\hline Avg. Growth Rate of GDP All Countries & $\begin{array}{l}-0.06 \\
{[0.04]}\end{array}$ & $\begin{array}{l}-0.02 \\
{[0.01]}\end{array}$ & $\begin{array}{c}0.06 \\
{[0.08]}\end{array}$ & $\begin{array}{l}-0.18 \\
{[0.09]}\end{array}$ \\
\hline Lagged Growth in per capita GDP & $\begin{array}{c}0.08 \\
{[0.02]^{\star \star}}\end{array}$ & $\begin{array}{c}0.04 \\
{[0.01]}\end{array}$ & $\begin{array}{c}0.02 \\
{[0.02]}\end{array}$ & $\begin{array}{c}0.12 \\
{[0.03]^{\star \star}}\end{array}$ \\
\hline Constant & $\begin{array}{c}-0.85 \\
{[0.12]^{\star \star}}\end{array}$ & $\begin{array}{c}-0.26 \\
{[0.06]^{*}}\end{array}$ & $\begin{array}{l}-1.37 \\
{[0.45]}\end{array}$ & $\begin{array}{c}0.07 \\
{[0.11]}\end{array}$ \\
\hline $\begin{array}{l}\text { Number of obs } \\
\text { R-squared }\end{array}$ & $\begin{array}{l}619 \\
0.41\end{array}$ & $\begin{array}{l}123 \\
0.36\end{array}$ & $\begin{array}{l}119 \\
0.23\end{array}$ & $\begin{array}{l}268 \\
0.46\end{array}$ \\
\hline
\end{tabular}

Notes: Dependent variable is the change in the ratio of the government surplus to GDP. All regressions include country fixed effects. Robust clustered standard errors re in parentheses. See the text for precise definitions of variables.

Absolute value of standardized beta coefficients are listed in row 2 after the estimated coefficients.

${ }^{*} p$-value $<0.1 ;{ }^{* *} p$-value $<0.05 ;{ }^{* \star *} p$-value $<0.01$

Table 12

Growth Dynamics vs. the Current Account, 1880-1913

\begin{tabular}{|c|c|c|c|c|}
\hline Regressors & $\begin{array}{l}\text { Pooled } \\
\text { (1) }\end{array}$ & $\begin{array}{c}\text { Core Ex Fin. Centers } \\
\text { ex. Offshoots } \\
\text { (2) }\end{array}$ & $\begin{array}{l}\text { Offshoots } \\
\text { (3) }\end{array}$ & $\begin{array}{c}\text { Periphery } \\
\text { (5) }\end{array}$ \\
\hline Change in Ratio of Current Account to GDP & $\begin{array}{c}0.09 \\
{[0.10]}\end{array}$ & $\begin{array}{c}0.11 \\
{[0.07]}\end{array}$ & $\begin{array}{l}-0.03 \\
{[0.14]}\end{array}$ & $\begin{array}{c}0.17 \\
{[0.13]}\end{array}$ \\
\hline Lagged Change in Ratio of Current Account to GDP & $\begin{array}{l}-0.02 \\
{[0.06]}\end{array}$ & $\begin{array}{c}0.06 \\
{[0.04]}\end{array}$ & $\begin{array}{c}0.29 \\
{[0.31]}\end{array}$ & $\begin{array}{l}-0.07 \\
{[0.07]}\end{array}$ \\
\hline Avg. Growth Rate of GDP All Countries & $\begin{array}{c}0.40 \\
{[0.13]^{\star *}}\end{array}$ & $\begin{array}{c}0.11 \\
{[0.06]}\end{array}$ & $\begin{array}{c}1.16 \\
{[0.48]}\end{array}$ & $\begin{array}{c}0.17 \\
{[0.17]}\end{array}$ \\
\hline Lagged Growth in per capita GDP & $\begin{array}{c}-0.24 \\
{[0.04]^{\star *}}\end{array}$ & $\begin{array}{l}-0.07 \\
{[0.09]}\end{array}$ & $\begin{array}{l}-0.22 \\
{[0.09]}\end{array}$ & $\begin{array}{c}-0.25 \\
{[0.07]^{\star \star}}\end{array}$ \\
\hline Constant & $\begin{array}{c}1.13 \\
{[0.20]^{\star *}}\end{array}$ & $\begin{array}{c}1.44 \\
{[0.10]^{\star *}}\end{array}$ & $\begin{array}{c}0.14 \\
{[0.71]} \\
\end{array}$ & $\begin{array}{c}1.41 \\
{[0.28]^{\star \star}}\end{array}$ \\
\hline $\begin{array}{l}\text { Number of obs } \\
\text { R-squared }\end{array}$ & $\begin{array}{l}756 \\
0.09\end{array}$ & $\begin{array}{l}155 \\
0.04\end{array}$ & $\begin{array}{l}128 \\
0.21\end{array}$ & $\begin{array}{l}345 \\
0.10\end{array}$ \\
\hline
\end{tabular}

Notes: Dependent variable is the growth rate of GDP per capita. All regression include country fixed effects. Robust clustered standard errors re in parentheses. See the text for precise definitions of variables.

${ }^{*} \mathrm{p}$-value $<0.1 ;{ }^{* *} \mathrm{p}$-value $<0.05 ;{ }^{* * *} \mathrm{p}$-value $<0.01$ 
Table 13

Growth Dynamics and Current Account Reversals, 1880-1913

\begin{tabular}{|c|c|c|c|c|c|c|c|}
\hline Regressors & $\begin{array}{l}\text { Pooled } \\
\text { (1) }\end{array}$ & $\begin{array}{l}\text { Core Ex Fin.Centers } \\
\text { ex. Offshoots } \\
\text { (2) }\end{array}$ & $\begin{array}{l}\text { Offshoots } \\
\text { (3) }\end{array}$ & $\begin{array}{c}\text { Periphery } \\
\text { (5) }\end{array}$ & $\begin{array}{l}\text { Openness } \\
\text { (6) }\end{array}$ & $\begin{array}{c}\text { Wealth } \\
\text { (7) }\end{array}$ & $\begin{array}{c}\text { Mismatch } \\
\text { (8) }\end{array}$ \\
\hline Current Account Reversalt & $\begin{array}{l}-0.52 \\
{[0.88]}\end{array}$ & $\begin{array}{c}1.09 \\
{[0.21]^{* *}}\end{array}$ & $\begin{array}{l}-1.14 \\
{[2.82]}\end{array}$ & $\begin{array}{l}-0.67 \\
-1.30]\end{array}$ & $\begin{array}{l}-2.72 \\
2.821\end{array}$ & $\begin{array}{l}-3.49 \\
{[7.24]}\end{array}$ & $\begin{array}{l}-1.12 \\
{[1.14]}\end{array}$ \\
\hline Current Account Reversal $t-1$ & $\begin{array}{l}-0.60 \\
{[0.99]}\end{array}$ & $\begin{array}{c}0.27 \\
{[0.15]}\end{array}$ & $\begin{array}{c}0.02 \\
{[4.04]}\end{array}$ & $\begin{array}{c}-0.95 \\
{[0.53]^{*}}\end{array}$ & $\ldots$ & $\ldots$ & $\ldots$ \\
\hline Current Account Reversal $t-2$ & $\begin{array}{c}-0.13 \\
{[0.84]}\end{array}$ & $\begin{array}{c}-0.75 \\
{[0.60]}\end{array}$ & $\begin{array}{c}-2.71 \\
{[0.90]^{\star}}\end{array}$ & $\begin{array}{c}1.20 \\
{[0.91]}\end{array}$ & -.- & $\ldots$ & -.- \\
\hline Current Account Reversal $t-3$ & $\begin{array}{l}0.85 \\
{[1.14]}\end{array}$ & $\begin{array}{l}-0.30 \\
{[0.54]}\end{array}$ & $\begin{array}{l}-0.27 \\
{[2.55]}\end{array}$ & $\begin{array}{c}2.34 \\
{[1.80]}\end{array}$ & -.- & $\ldots$ & -.- \\
\hline Current Account Reversal $t$ X Exports/GDP & $\ldots$ & $\ldots$ & $\ldots$ & 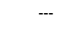 & $\begin{array}{c}0.08 \\
{[0.10]}\end{array}$ & $\ldots$ & -.- \\
\hline Current Account Reversal $t$ X Lagged GDP per Capita & $\cdots$ & -.- & $\ldots$ & -- & $\ldots$ & $\begin{array}{c}0.38 \\
{[0.97]}\end{array}$ & -.- \\
\hline Current Account Reversal $t \mathrm{X}$ Currency Mismatch & $\cdots$ & $\ldots$ & -.. & -- & $\cdots$ & $\ldots-$ & $\begin{array}{c}0.77 \\
{[1.03]}\end{array}$ \\
\hline Exports/GDP & $\cdots$ & -.- & -. & -- & $\begin{array}{c}0.01 \\
{[0.02]}\end{array}$ & ... & --- \\
\hline Lagged GDP per Capita & $\cdots$ & $\ldots$ & -.- & $\ldots$ & ... & $\begin{array}{c}-3.32 \\
{[0.97]^{* * *}}\end{array}$ & -.- \\
\hline Mismatch & $\cdots$ & $\ldots$ & $\ldots$ & -- & -.- & --- & $\begin{array}{c}-0.15 \\
{[0.14]}\end{array}$ \\
\hline Avg. Growth Rate of GDP per capita all countries & $\begin{array}{c}0.44 \\
{[0.13]^{* *}}\end{array}$ & $\begin{array}{c}0.10 \\
{[0.05]}\end{array}$ & $\begin{array}{c}1.26 \\
{[0.51]}\end{array}$ & $\begin{array}{c}0.25 \\
{[0.16]}\end{array}$ & $\begin{array}{c}0.44 \\
{[0.13]^{* *}}\end{array}$ & $\begin{array}{c}0.46 \\
{[0.13]^{* *}}\end{array}$ & $\begin{array}{c}0.55 \\
{[0.16]^{* * *}}\end{array}$ \\
\hline Constant & $\begin{array}{c}0.75 \\
{[0.20]^{* *}}\end{array}$ & $\begin{array}{c}1.31 \\
{[0.09]^{* *}}\end{array}$ & $\begin{array}{c}0.05 \\
{[0.68]}\end{array}$ & $\begin{array}{c}0.84 \\
{[0.28]^{*}}\end{array}$ & $\begin{array}{c}0.57 \\
{[0.43]}\end{array}$ & $\begin{array}{c}26.23 \\
{[7.44]^{* *}}\end{array}$ & $\begin{array}{c}0.75 \\
{[0.23]^{* * *}}\end{array}$ \\
\hline $\begin{array}{l}\text { Number of obs } \\
\text { R-squared }\end{array}$ & 730 & 150 & 124 & 332 & 787 & 787 & 582 \\
\hline
\end{tabular}


Figure 1

Privilege: Relative to GDP, U.S.A now

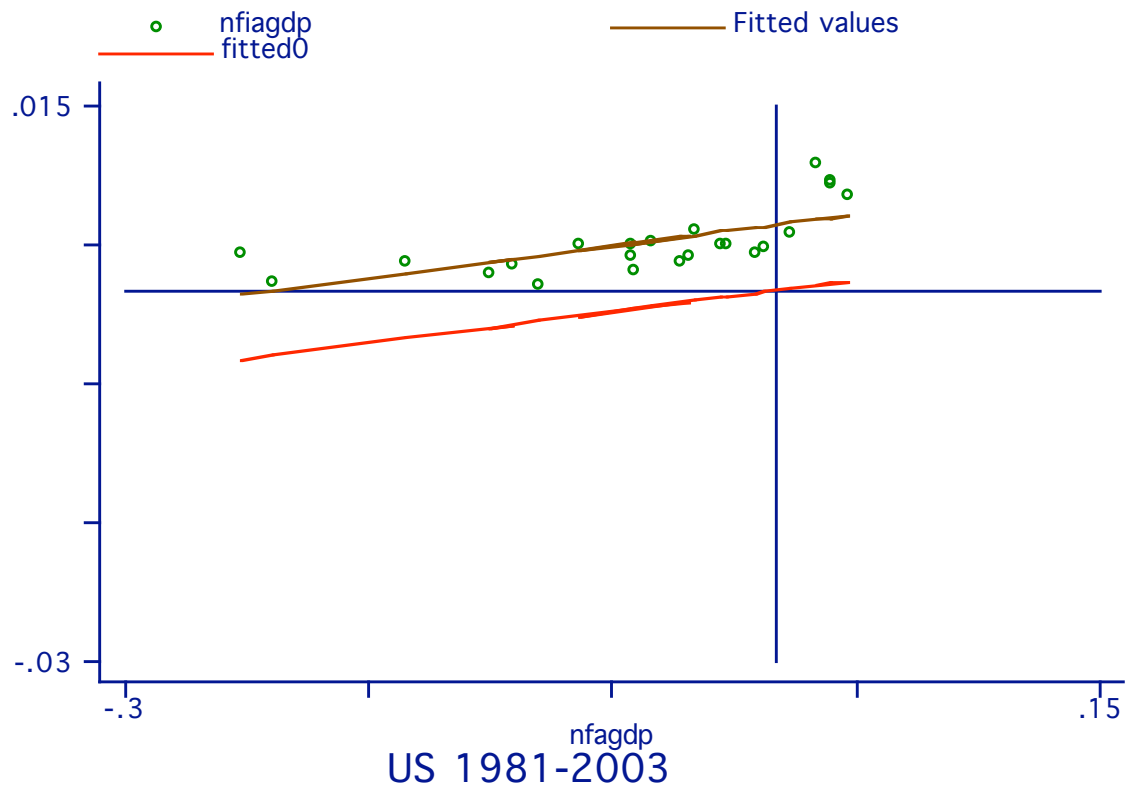

Figure 2

Privilege: Relative to GDP, G7 now

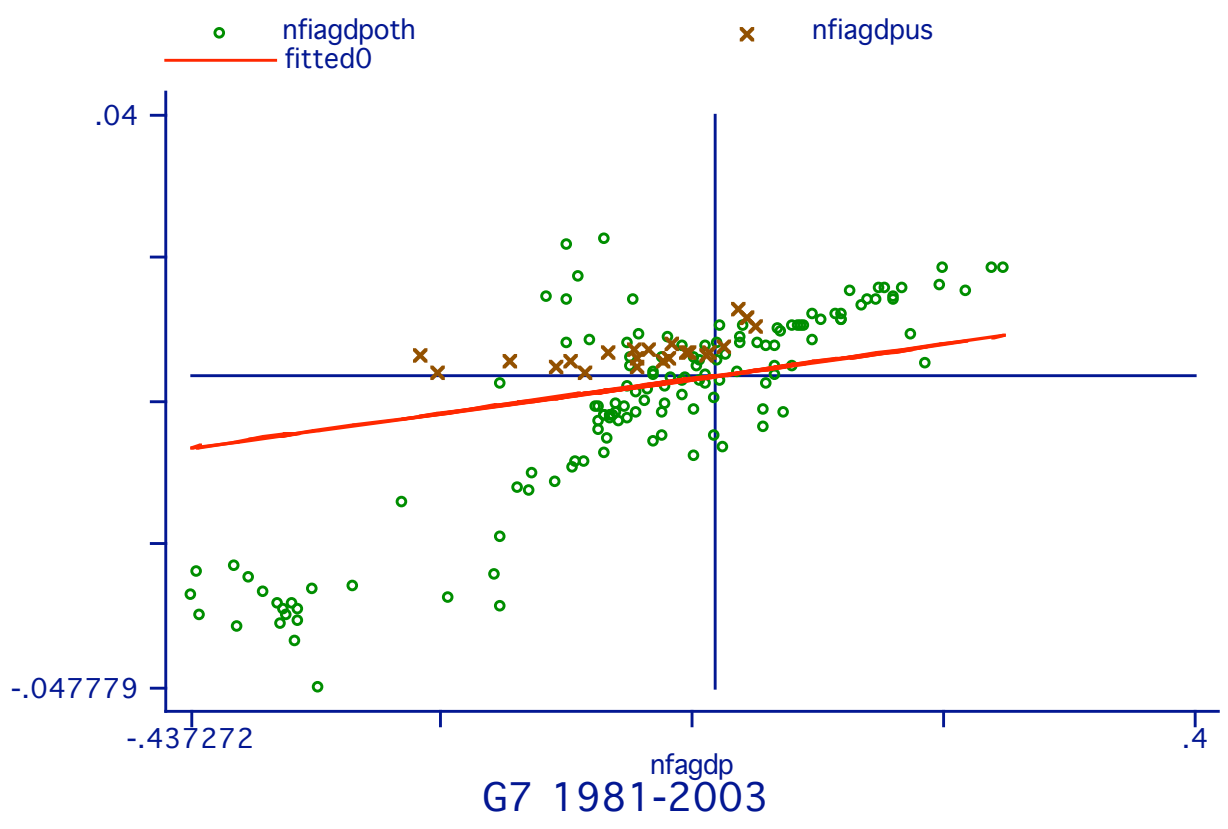


Figure 3

Privilege: Relative to GDP, Britain then

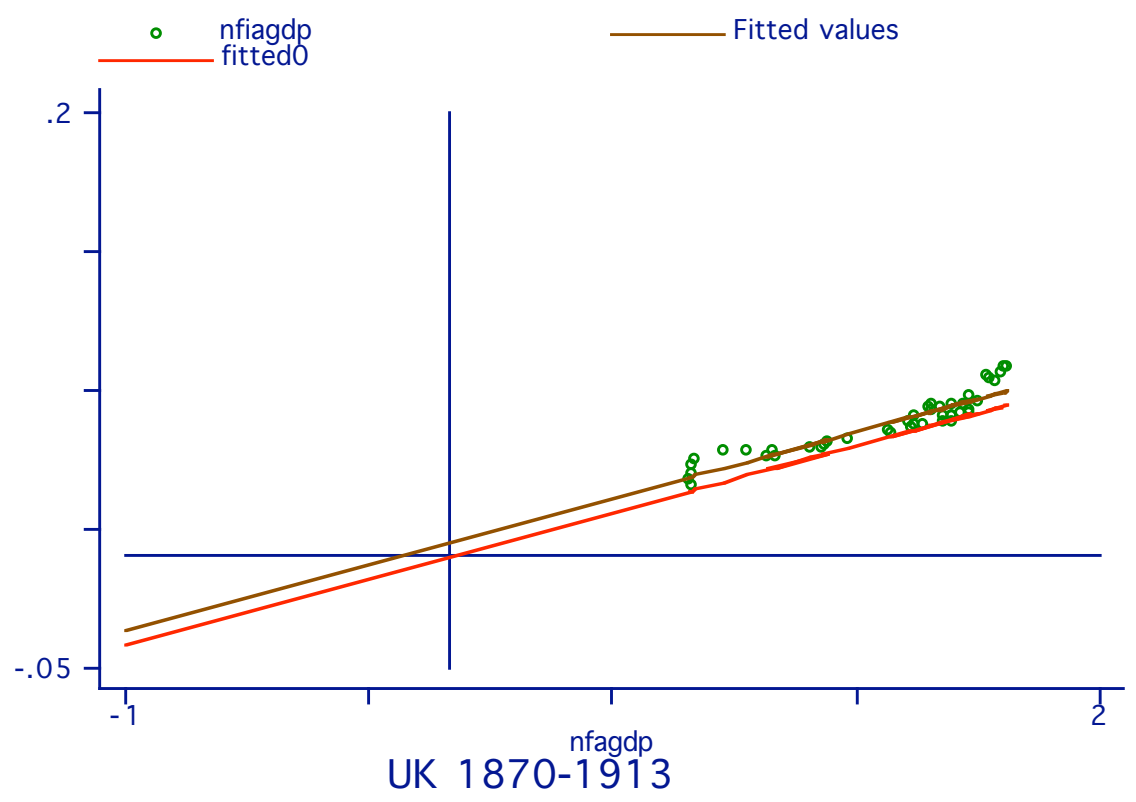

Figure 4

Privilege: Relative to GDP, Trends U.K. then and U.S. now

U.K. then

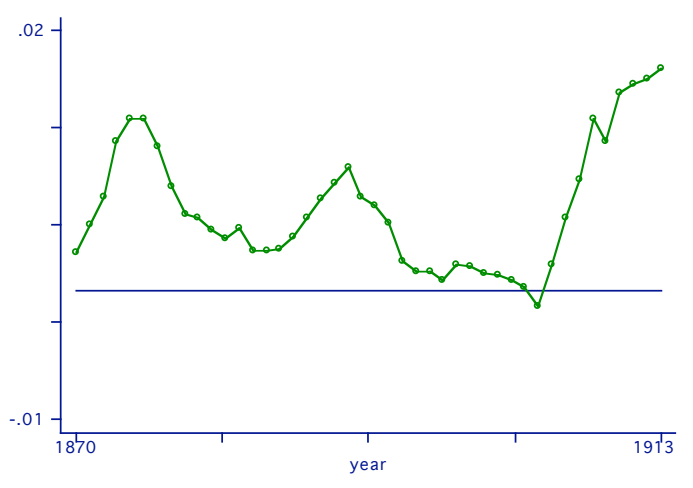

U.S. now

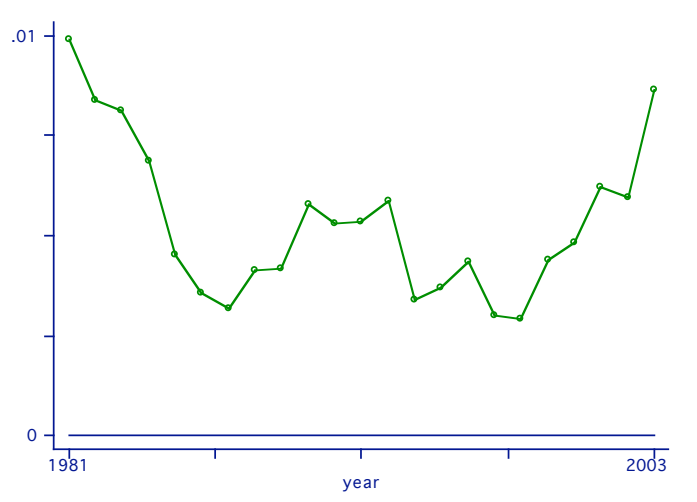


Figure 5

Not Much Privilege: U.K. 1870-1913

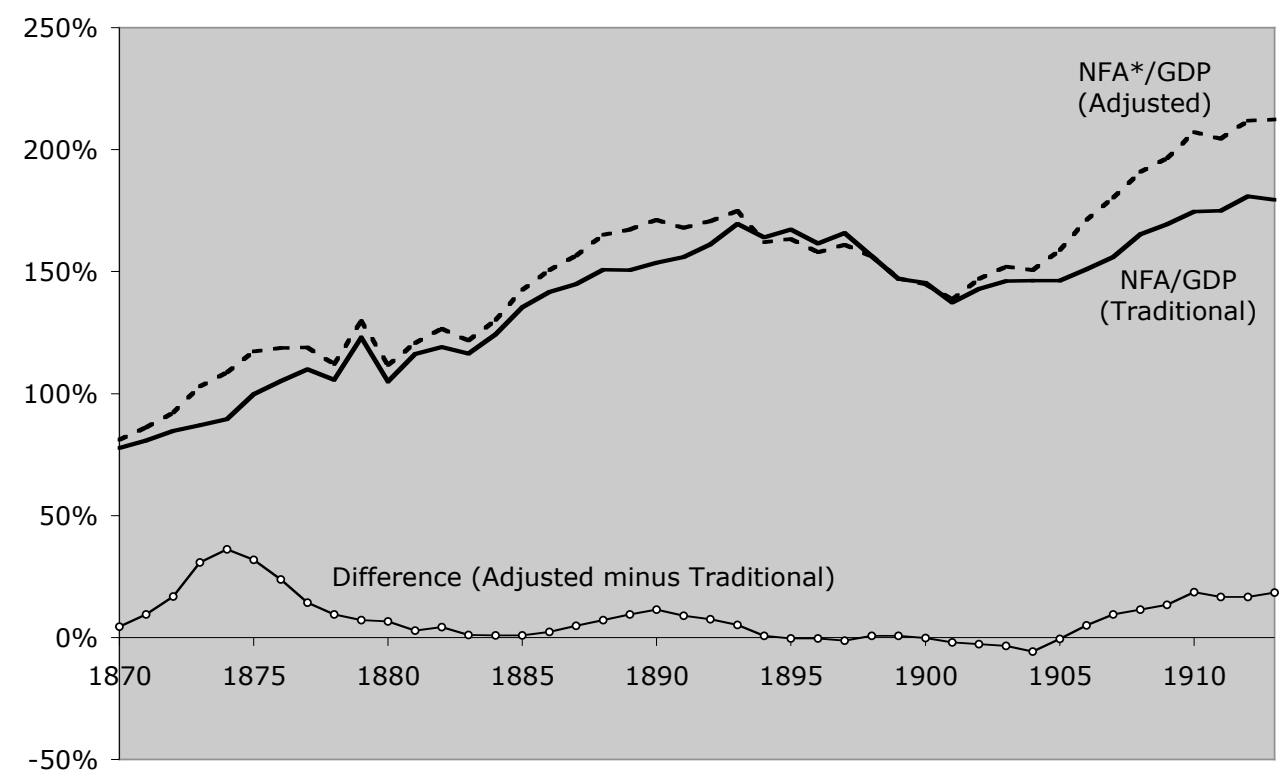

Note: This figure uses a $4 \%$ discount rate (or a Hausmann-Sturzenegger $\mathrm{PE}$ ratio of 25) based on the estimated yield in Table 1.

\section{Figure 6}

Rate of Yield on British Investments

Selected Home and Overseas Firms 1870-1913

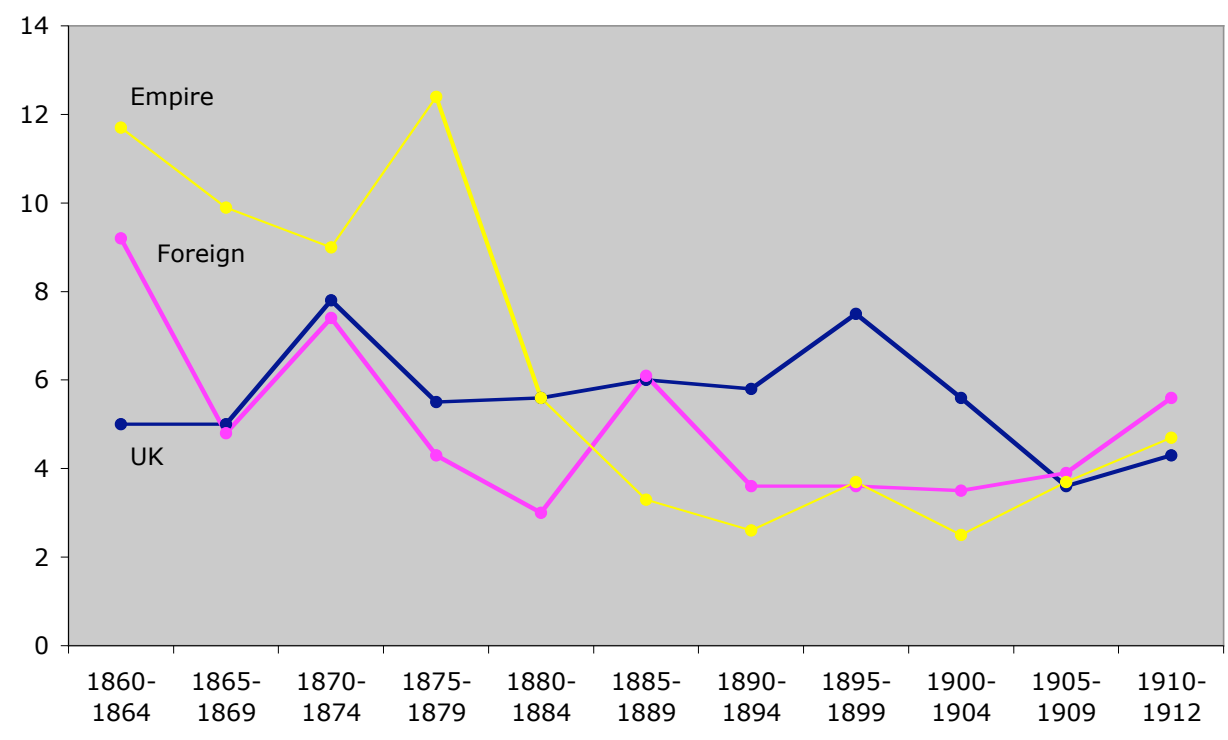

Source: Davis and Huttenback (1986). 
Figure 7

Yield to Maturity on Sovereign Bonds, 1870-1913
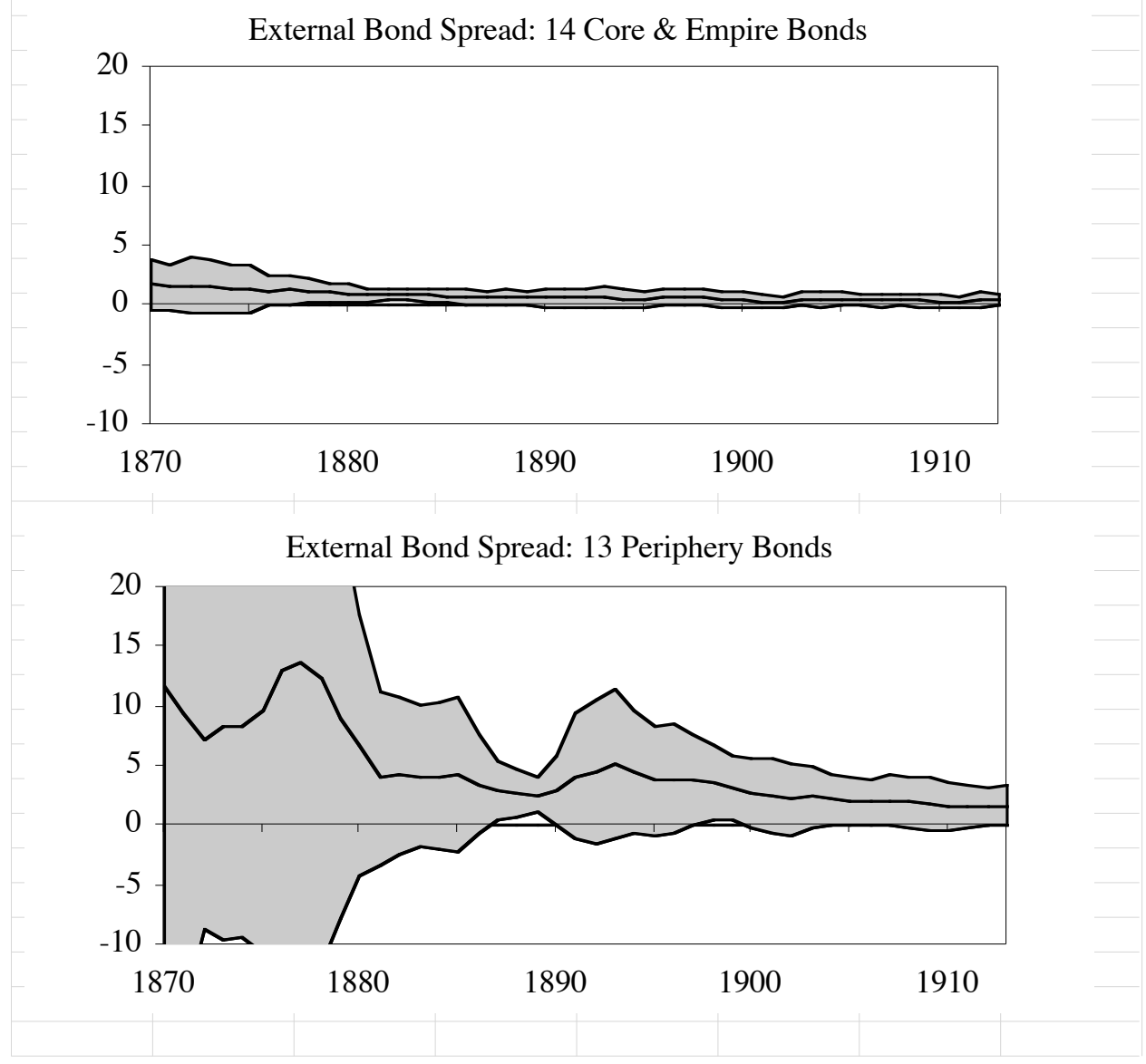

Source: Obstfeld and Taylor (2004). 
Figure 8

U.S. Rates of Yield and Differentials

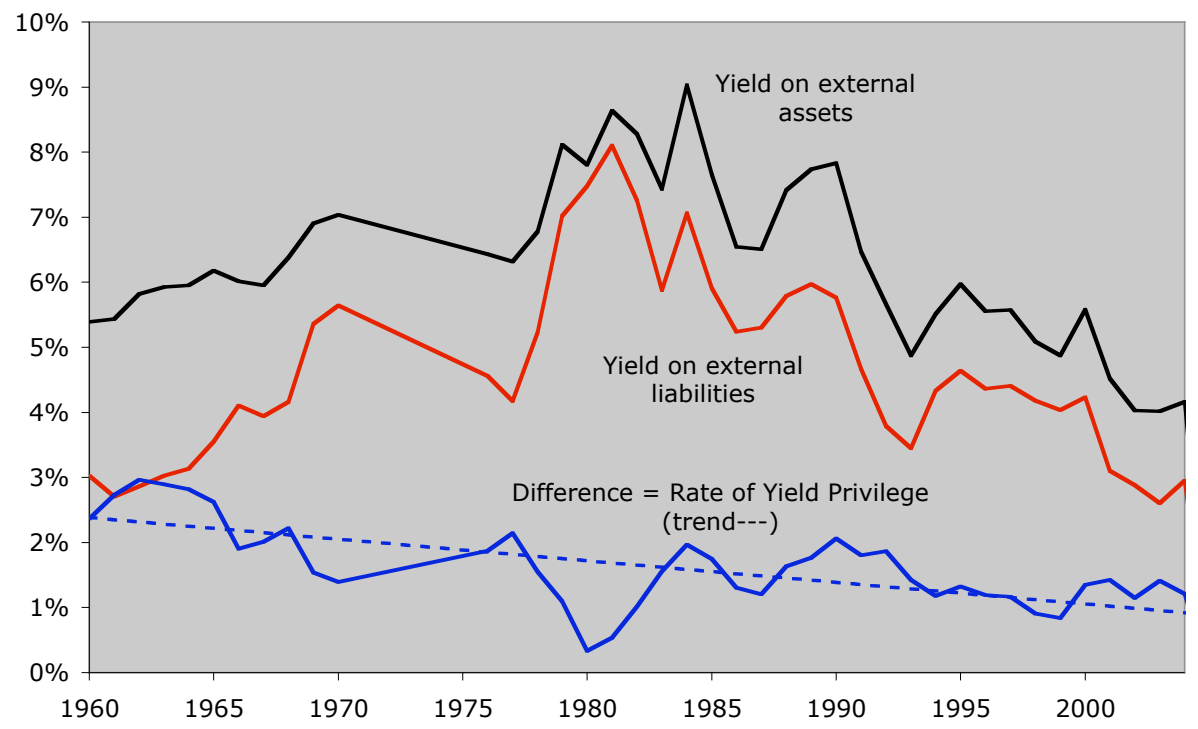

Sources: BEA, Historical Statistics

Figure 9

U.S. Rates of Yield and Differentials: Comparison with G7

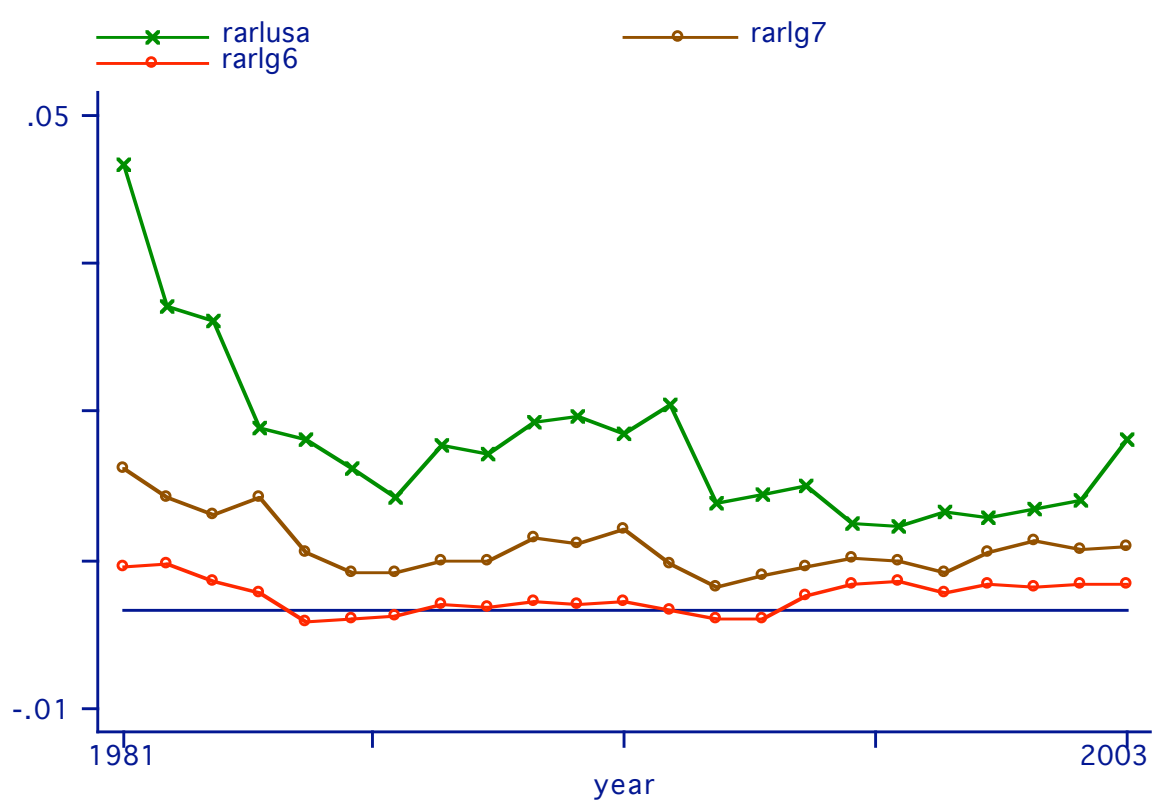

G6 (G7 ex. U.S.) and G7 are averages weighted by positions, i.e. total income divided by total position, for all 6 or 7 countries, expressed in U.S.D.

Sources: IFS, Lane and Milesi-Ferretti (2004) 
Figure 10

What Might Have Been: U.S. Investment Income Privilege as a Fraction of GDP, Actual (declining yield differentials) versus counterfactual (constant yield differentials at 1960s level), 1965-2004

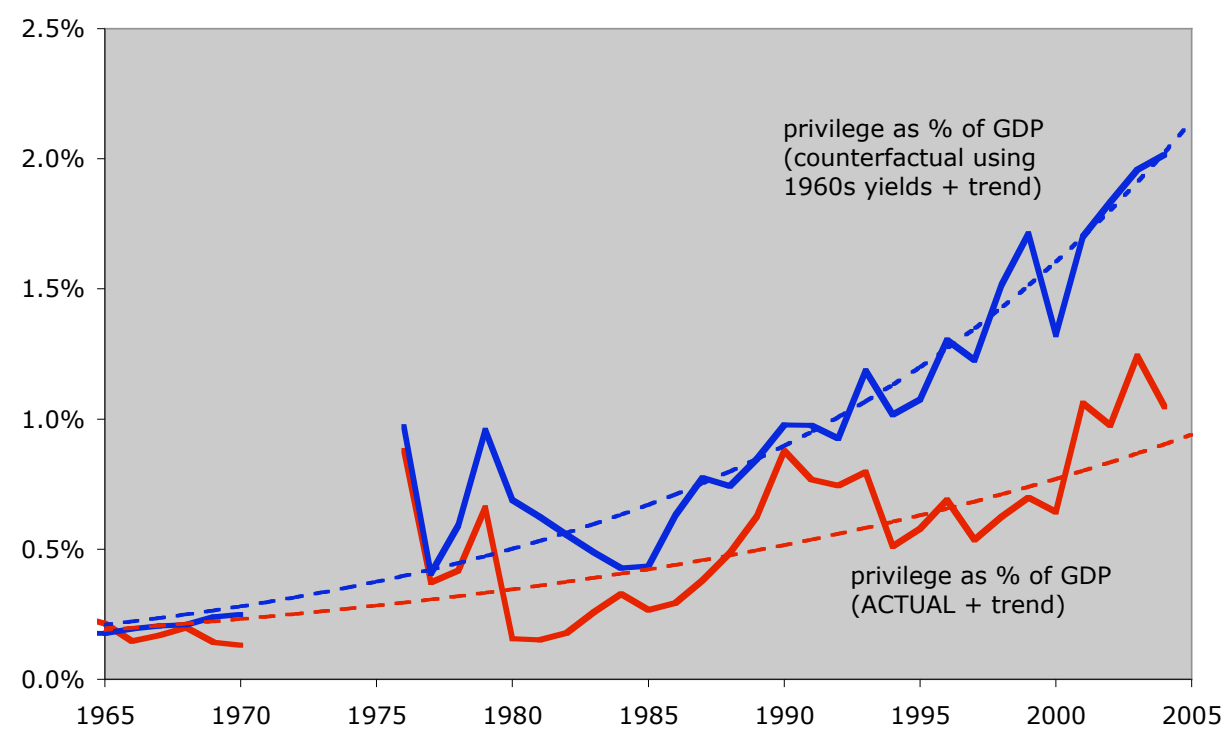

Figure 11

U.S. Total Rate of Return Differentials: Comparison with G7

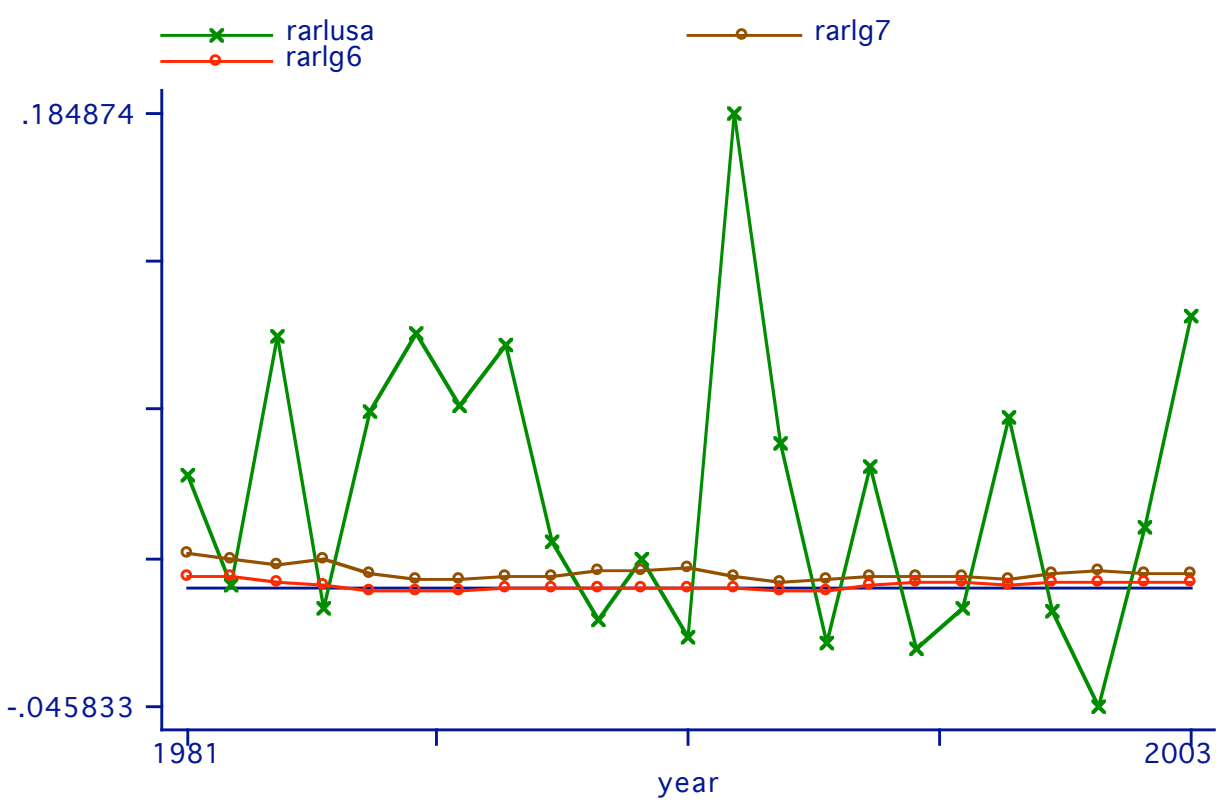

G6 (G7 ex. U.S.) and G7 are averages weighted by positions, i.e. total income and capital gain divided by total position, for all 6 or 7 countries, expressed in U.S.D.

Sources: IFS, Lane and Milesi-Ferreti (2004) 
Figure 12

U.K. Total Rate of Return, Samples of Securities

a) All

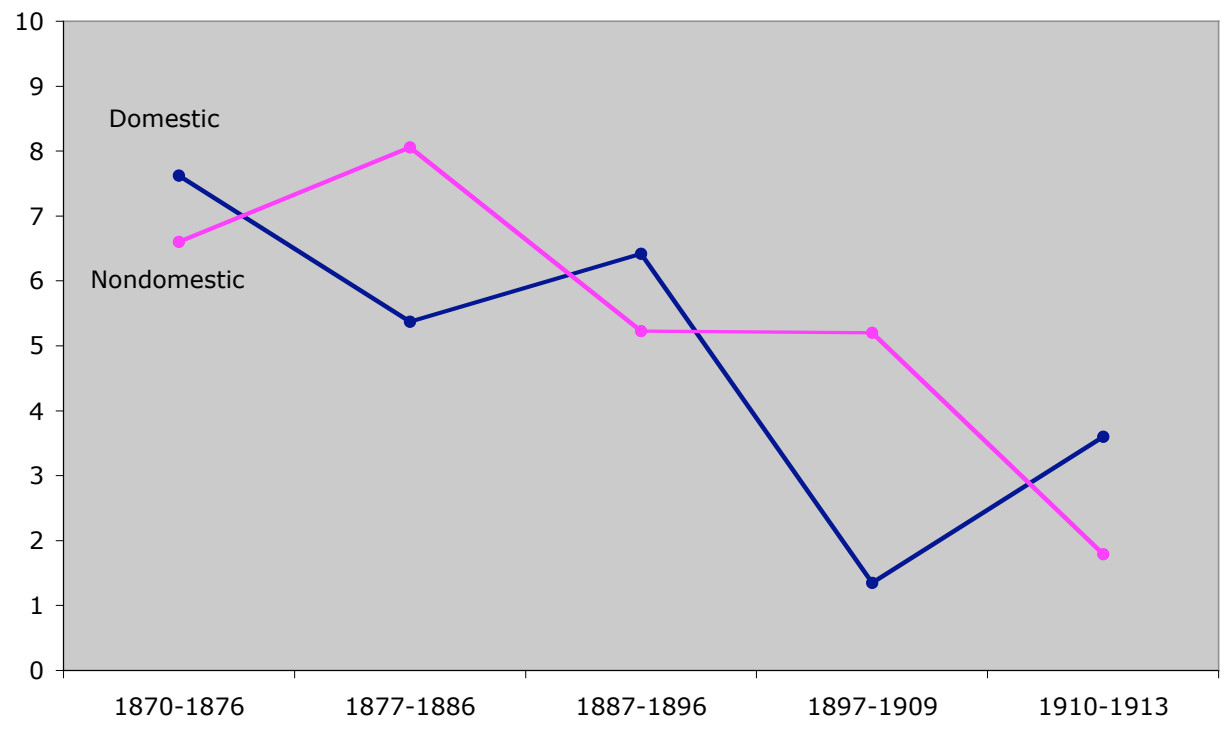

b) Debentures

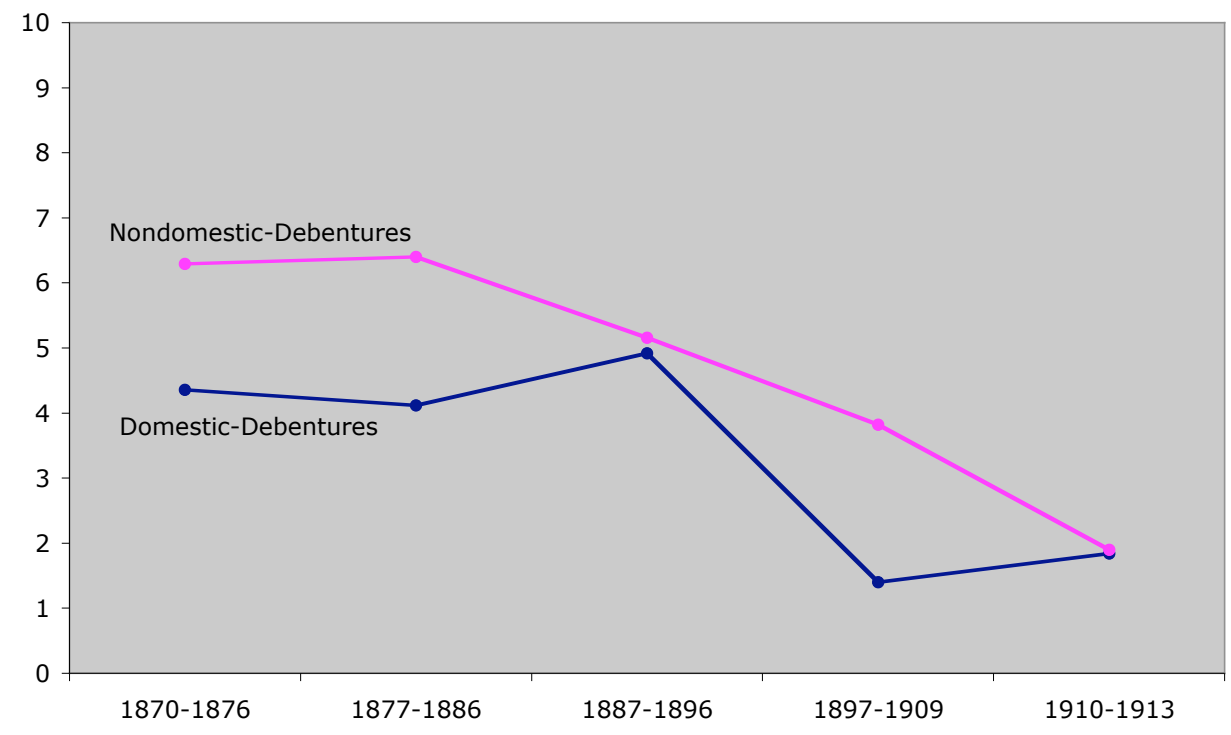


Figure 13

Box and Whisker Plot:

Current Account Surplus for All Countries, 1880-1913

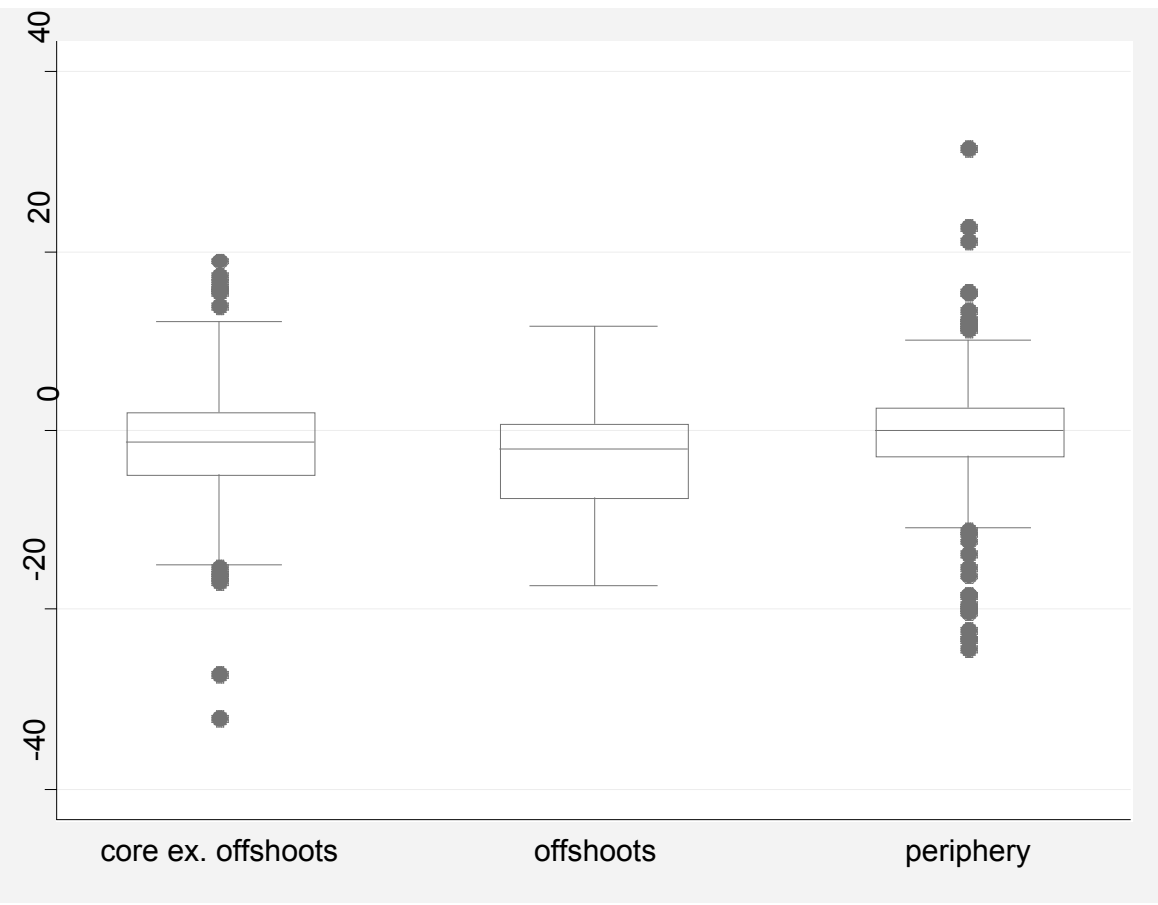

Figure 14

Box and Whisker Plot:

Current Account Surplus for Rich vs. Poor Countries, 1880-1913

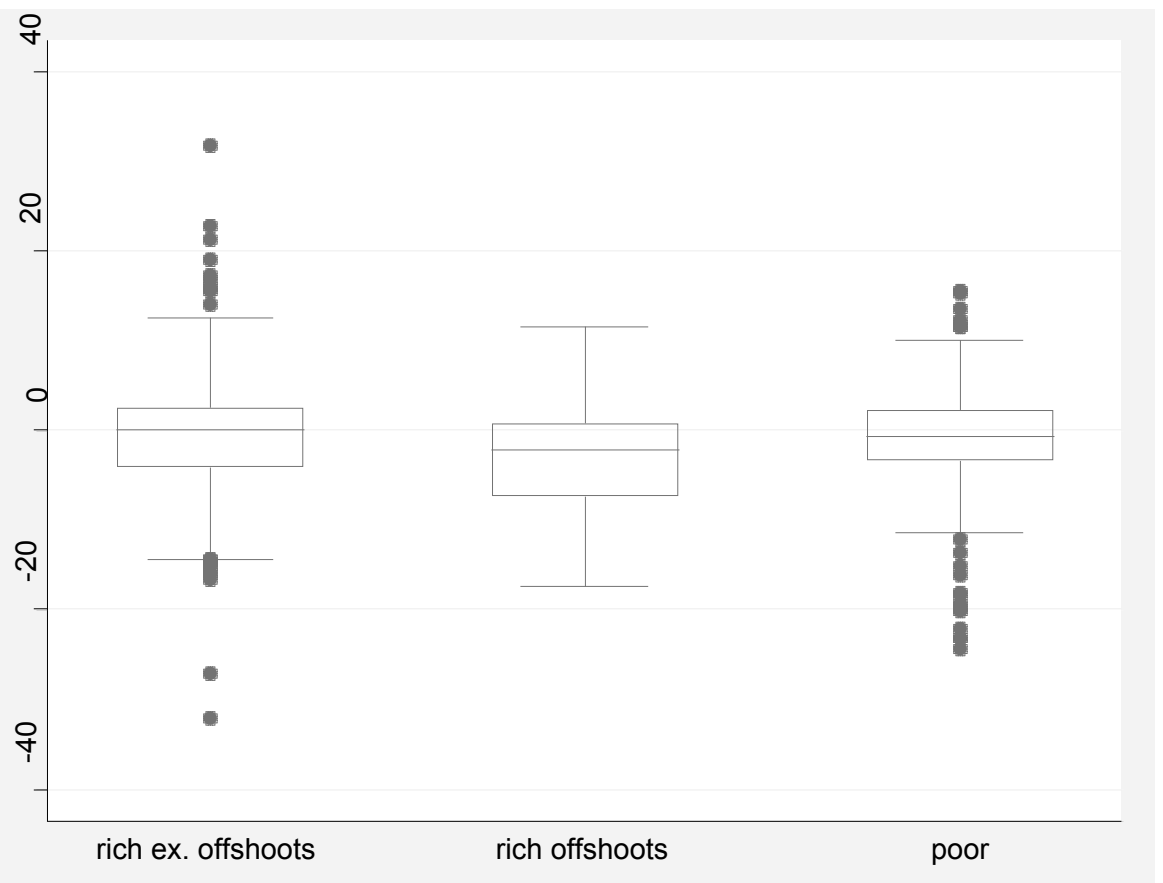


Figure 15

Arithmetic Average of the Current Account Surplus in Periphery, Offshoots, and Core, 1880-1913

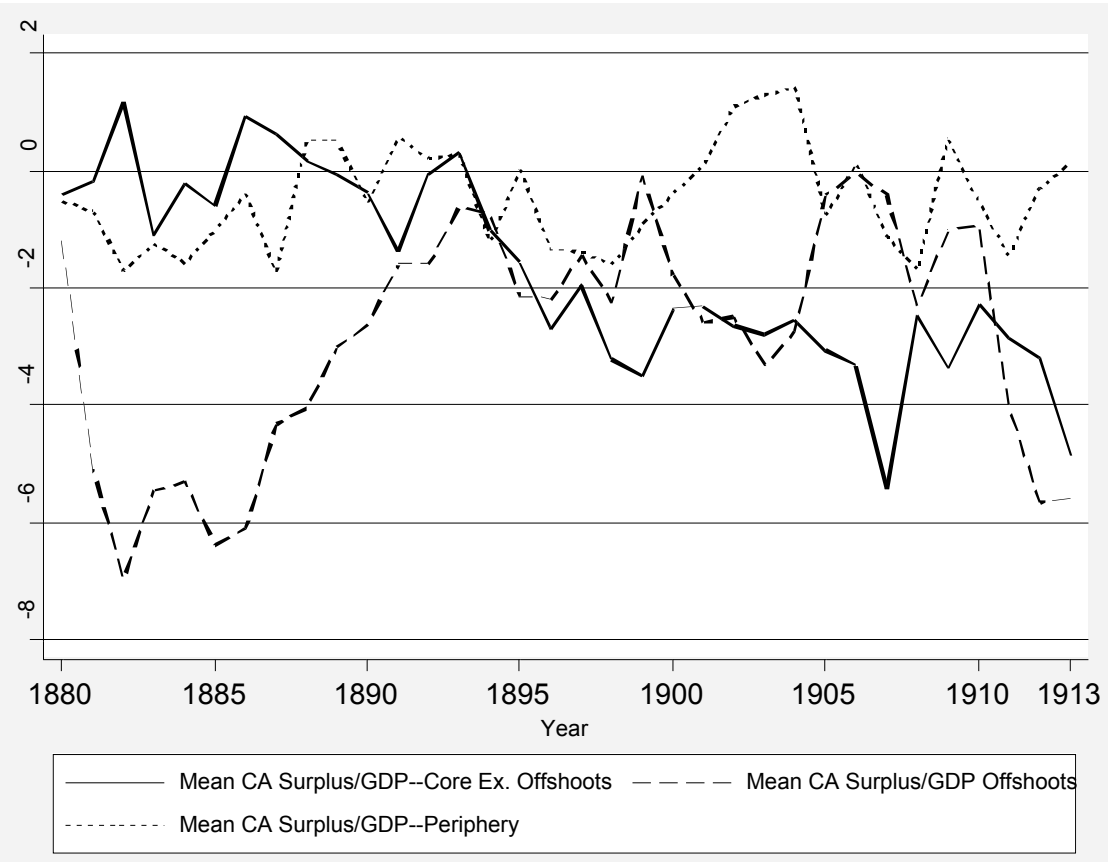

Figure 16

Arithmetic Average of the Current Account Surplus in Rich and Poor Countries, 1880-1913

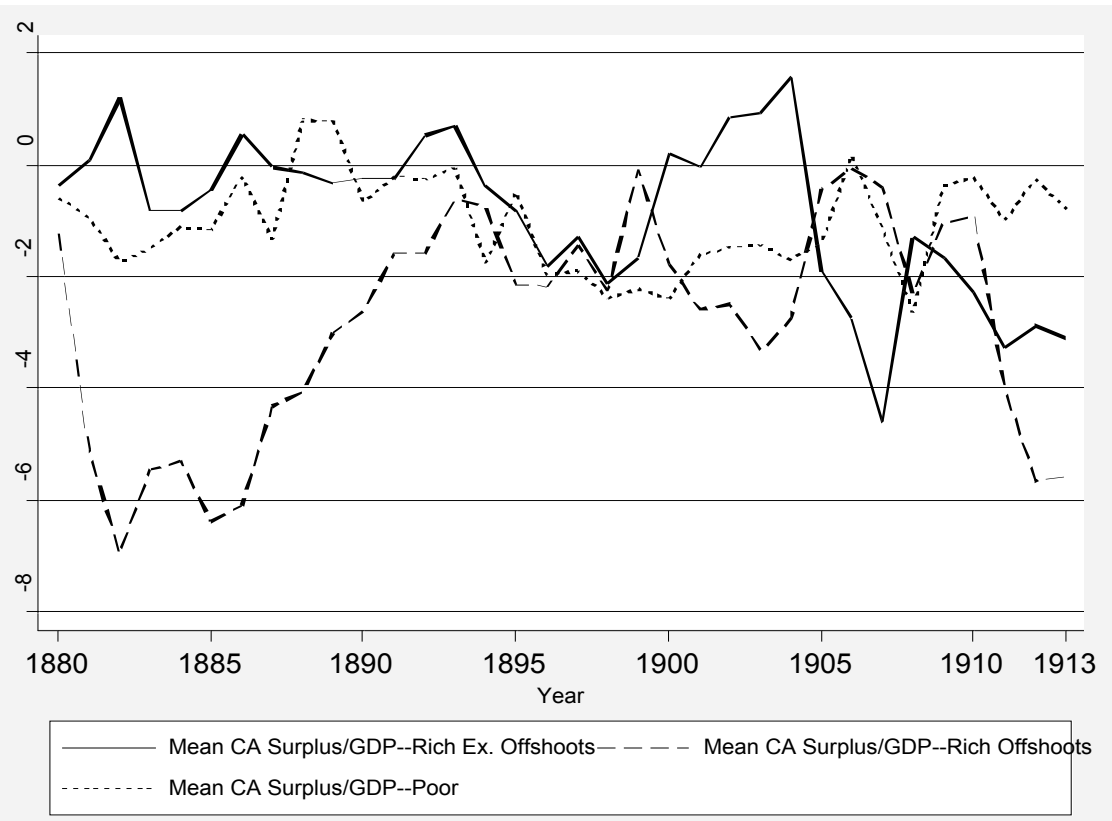


Figure 17

GDP-Weighted Average Current Account Deficits, Core and Periphery, 1880-1913

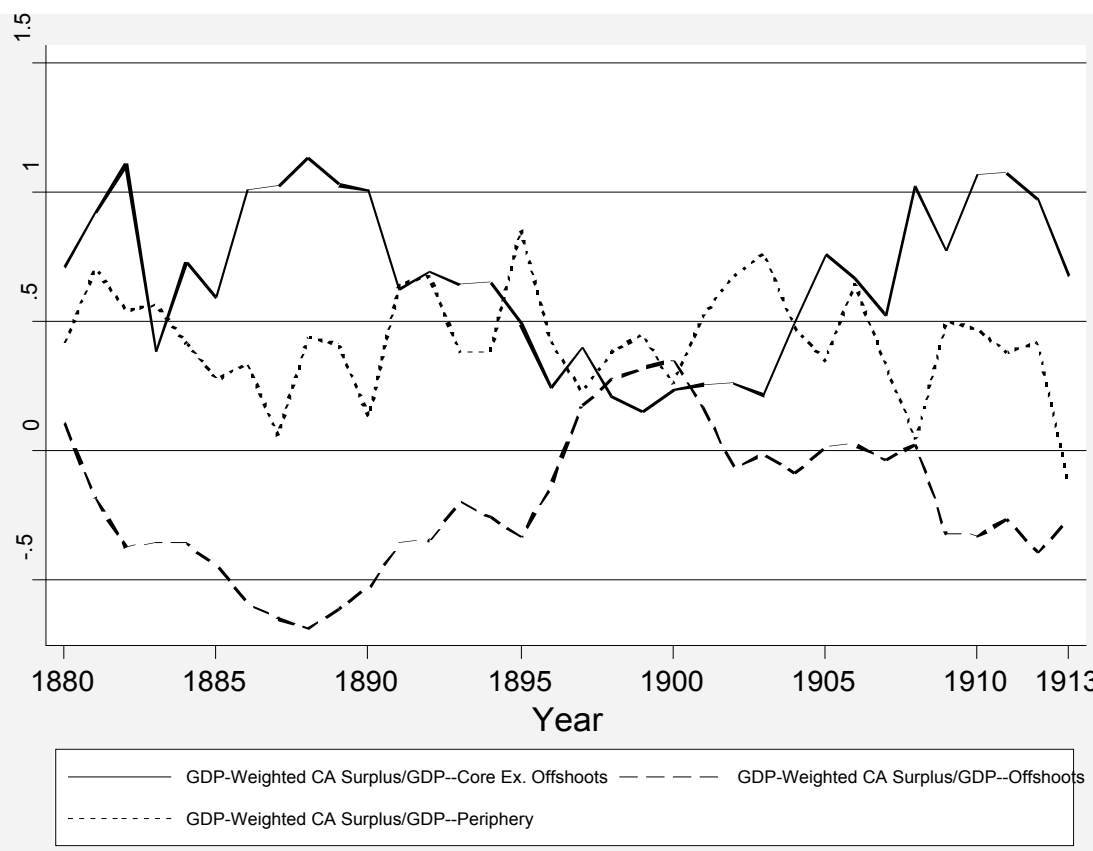

Figure 18

Adjustment Parameters, 1880-1913

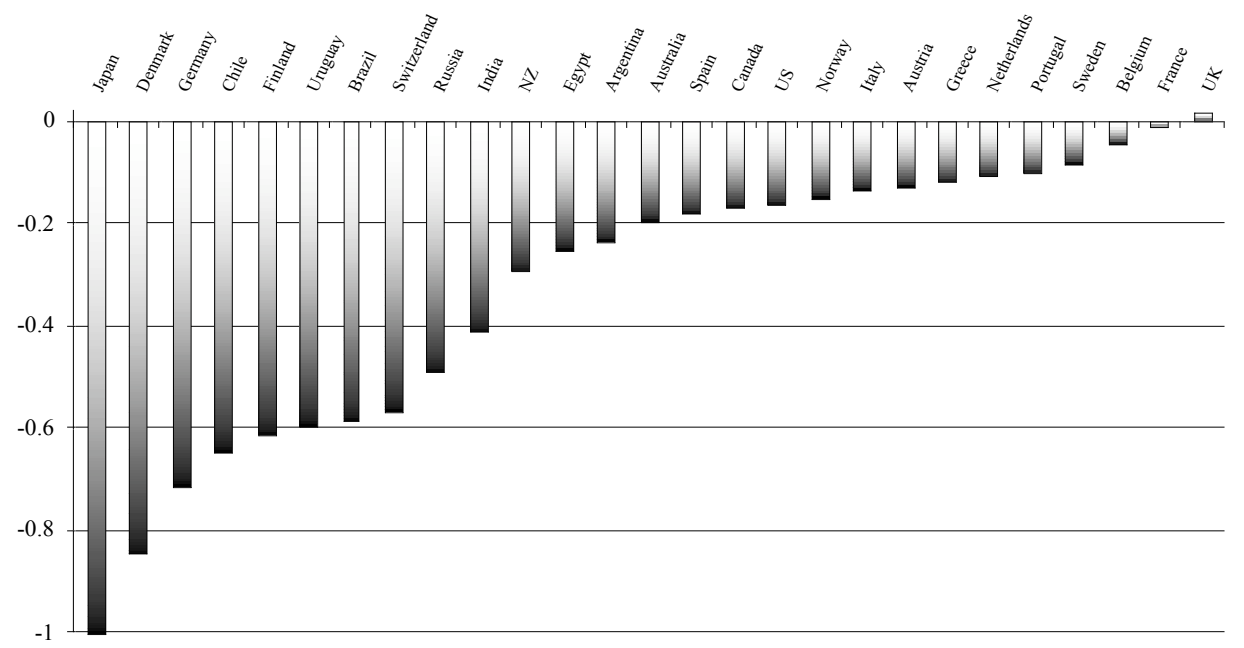


Figure 19

Average Current Account Levels Before and After a Reversal, Various Groups

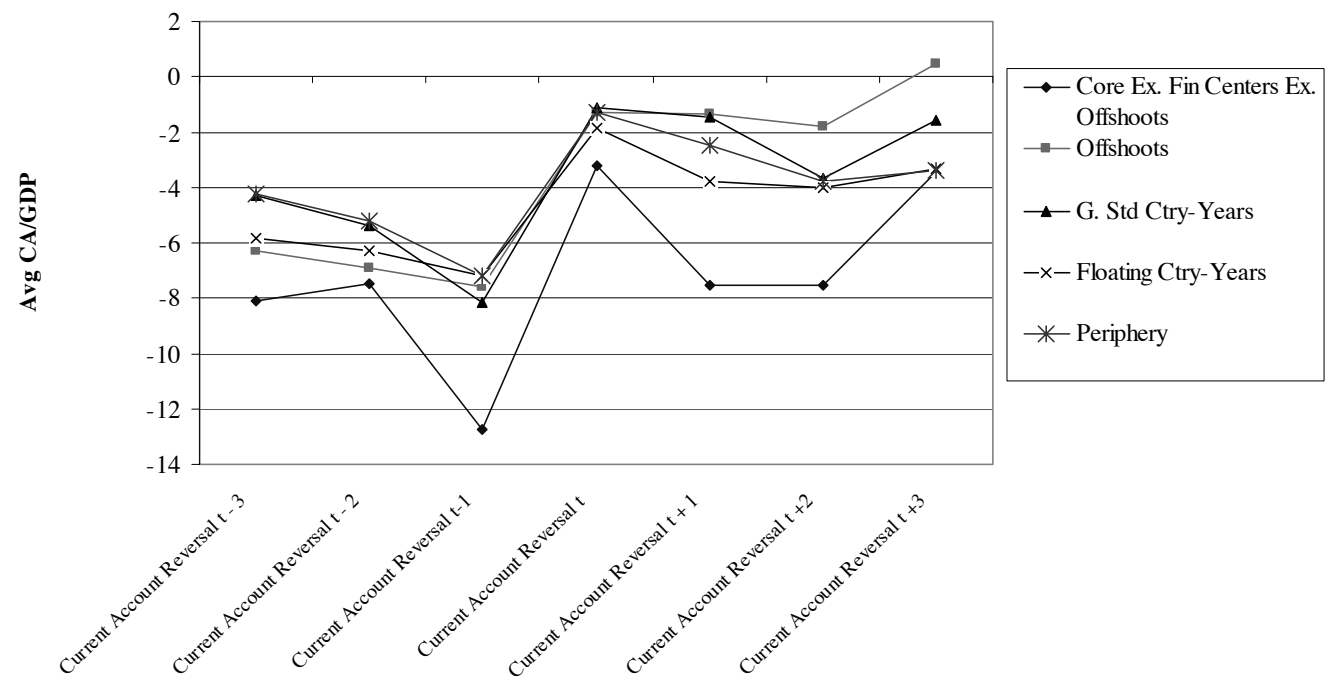

Figure 20

Average Real Exchange Rates Before and After Current Account Reversals

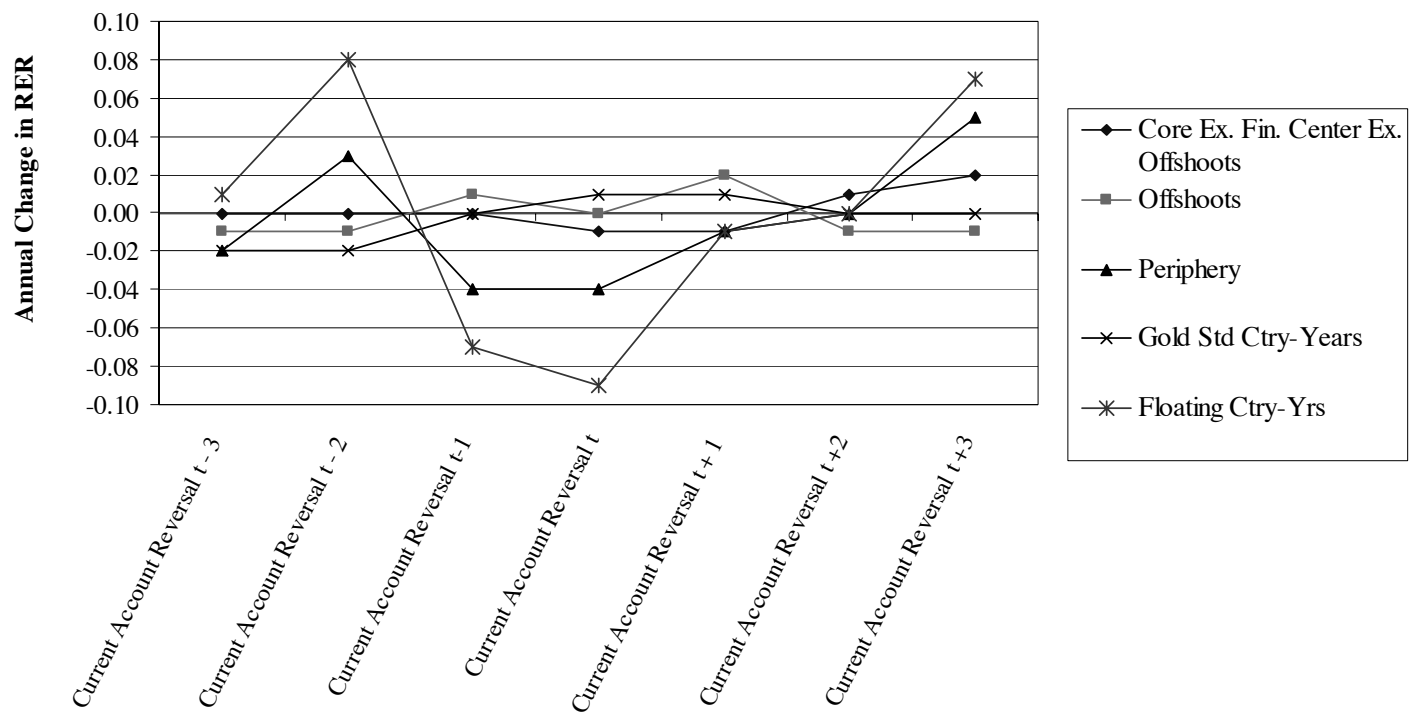


Figure 21

Average and Median Changes in Real Exchange Rates Before, During and After a Current Account Reversal

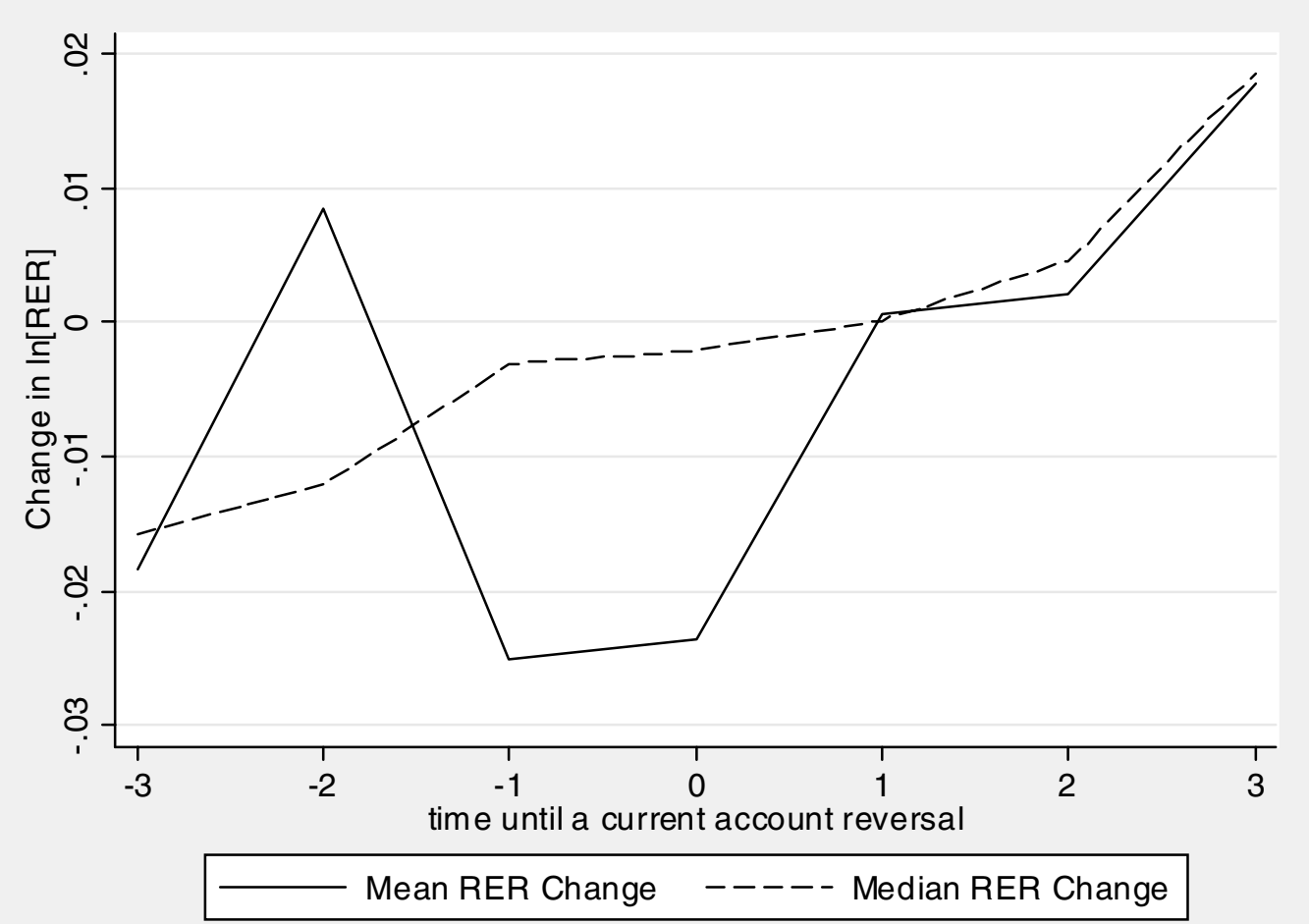




\section{Data Sources and Notes}

\section{Countries in our econometric samples}

Argentina (SI), Australia (SI), Austria-Hungary, Belgium, Brazil, Canada (SI), Denmark (SI), Egypt, Finland (SI), France (SI), Germany (SI), Greece, India, Italy (SI), Japan (SI), Netherlands (SI), New Zealand, Norway (SI), Portugal, Russia, Spain (SI), Sweden (SI), Switzerland, United Kingdom (SI), United States (SI), Uruguay

Not all countries appear in each of the 34 years which we analyze. (SI) indicates the subset of 15 countries which are included in the regressions with the savings and investment ratios.

\section{Current Accounts}

Current accounts for Australia, Canada, Denmark, Finland, France, Germany, Italy, Japan, Norway, Russia, Sweden, United Kingdom, and the United States are from Jones and Obstfeld Saving, Investment, and Gold: A Reassessment of Historical Current Account Data available at http://www.nber.org/databases/jones-obstfeld/

For the Netherlands the source is Smits, Horlings, and van Zanden (2000) at http://nationalaccounts.niwi.knaw.nl/start.htm Calculated as GNP-GDP + Net exports of merchandise and services

For Chile the current account statistics come from Braun, Briones Díaz, Lüders, and Wagner (2000) while GDP statistics from Obstfeld and Taylor (2003).

For all other countries we used the trade balance as a proxy for the current account balance.

GDP and GDP per capita: Data underlying Obstfeld and Taylor (2003)

Real Exchange Rates: Data underlying Bordo, et al (2001).

Savings and Investment Ratios: Taylor (2003)

Government Surplus: Data underlying Bordo, et al (2001).

Exports GDP: Data underlying Obstfeld and Taylor (2003)

Currency Mismatch: Data underlying Bordo and Meissner (forthcoming) 